University of Louisville

ThinkIR: The University of Louisville's Institutional Repository

$5-2012$

\title{
Discussion board posts about Jewish interfaith relationships and intermarriage : romantic love, independence, concern for children, and ethnicity.
}

Miriam Kan 1981-

University of Louisville

Follow this and additional works at: https://ir.library.louisville.edu/etd

\section{Recommended Citation}

Kan, Miriam 1981-, "Discussion board posts about Jewish interfaith relationships and intermarriage : romantic love, independence, concern for children, and ethnicity." (2012). Electronic Theses and Dissertations. Paper 723.

https://doi.org/10.18297/etd/723

This Master's Thesis is brought to you for free and open access by ThinkIR: The University of Louisville's Institutional Repository. It has been accepted for inclusion in Electronic Theses and Dissertations by an authorized administrator of ThinkIR: The University of Louisville's Institutional Repository. This title appears here courtesy of the author, who has retained all other copyrights. For more information, please contact thinkir@louisville.edu. 
DISCUSSION BOARD POSTS ABOUT JEWISH INTERFAITH RELATIONSHIPS

AND INTERMARRIAGE: ROMANTIC LOVE, INDEPENDENCE, CONCERN FOR CHILDREN, AND ETHNICITY

\author{
By \\ Miriam Kan \\ B.A., University of Montana, 2003

\begin{abstract}
A Thesis
Submitted to the Faculty of the

College of Arts and Sciences of the University of Louisville in Partial Fulfillment of the Requirements

for the Degree of
\end{abstract}

Master of Arts

Department of Communication

University of Louisville

Louisville, Kentucky

May 2012 


\title{
DISCUSSION BOARD POSTS ABOUT JEWISH INTERFAITH RELATIONSHIPS AND INTERMARRIAGE: ROMANTIC LOVE, INDEPENDENCE, CONCERN FOR CHILDREN, AND ETHNICITY
}

\author{
By \\ Miriam Roccanova Kan \\ B.A., University of Montana, 2003
}

A Thesis Approved on

April 19, 2012

by the Following Thesis Committee:

John P. Ferré, PhD

Greg B. Leichty, PhD

Jasmine Farrier, $\mathrm{PhD}$ 


\author{
ABSTRACT \\ DISCUSSION BOARD POSTS ABOUT JEWISH INTERFAITH RELATIONSHIPS \\ AND INTERMARRIAGE: ROMANTIC LOVE, INDEPENDENCE, \\ CONCERN FOR CHILDREN, AND ETHNICITY \\ Miriam Kan
}

April 19, 2012

Following previous studies on the rate of increase and behavior of the American Jewish intermarried, this study sought to determine what individuals are discussing about Jewish interfaith relationships and intermarriage. Four scholarly issues were identified as topics of concern: romantic love, independence, concern for children, and ethnicity. Two Internet discussion boards, interfaithfamily.com and joi.org, were analyzed using the four topics as a basis for narrative analysis. The messages analyzed on interfaithfamily.com and joi.org showed that these four topics are not restricted to the scholarly literature, but are also discussed in public among individuals concerned with Jewish interfaith relationships and intermarriage who come from a mix of religious affiliations. Nearly three quarters of the population posting comments on the discussion boards were women, who identified themselves broadly as either Jewish or Christian. The findings suggest that individuals discuss all four of these topics. 
TABLE OF CONTENTS

PAGE

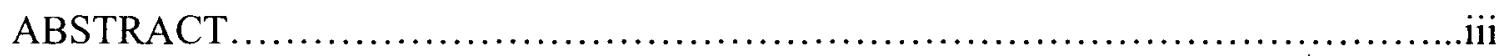

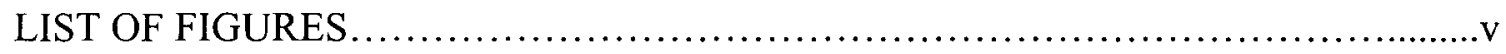

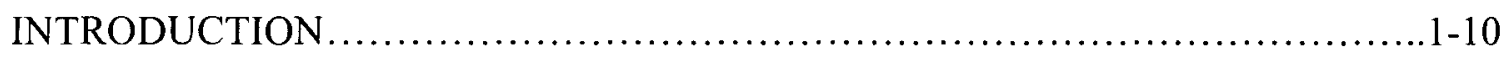

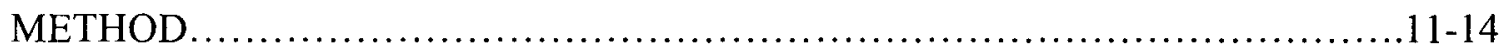

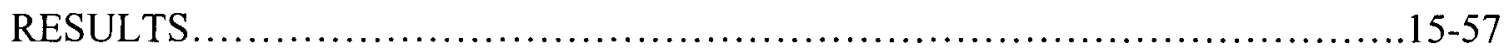

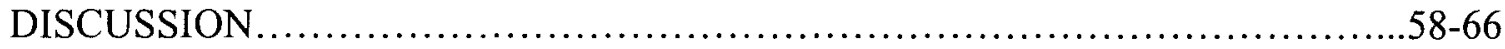

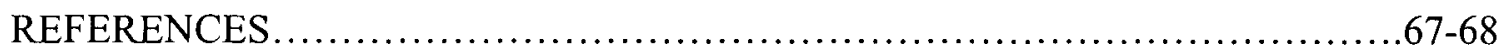




\section{LIST OF FIGURES}

FIGURE

$1.1 \quad$ Percent Coded Topics................................................. 59

1.2 Posts According to Religious Affiliation.................................62

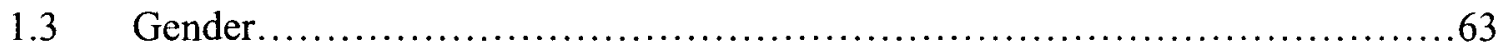

1.4 Topic and Religious Affiliation...........................................64 


\section{CHAPTER I}

\section{INTRODUCTION}

Jewish intermarriage in the United States has increased steadily since the middle

of the twentieth century. In Jew vs. Jew, Samuel G. Freedman recounts, "From the early twenties through the late fifties, the share of such marriages crept up only from 1.7 to 6.6 percent; such shame attached to 'marrying out' that Jewish parents often observed the mourning ritual of Shiva for a child who did so" (72). But since the 1960s when Americans began to integrate across racial, cultural, and religious boundaries, Jewish intermarriage has accelerated. "The percentage of interfaith marriages nearly doubled in the early sixties and almost tripled during the late sixties and early seventies, reaching about one-third," Freedman says, observing that Jewish tribal unity has given way to American individualism to such an extent that more than half of Jewish marriages today are exogamous (73). Children born into families with blended religious and ethnic identities are apt to lead secular lives detached from Judaism. Freedman reports, “Only 28 percent of intermarried couples were raising their children solely as Jews; only 13 percent of intermarried couples were affiliated with any branch of Judaism. One in six households that called itself Jewish in the 1990 survey had no member who was a Jew by birth or formal conversion" (73).

The current Jewish population in the United States is relatively small. The Jewish population in 2010 was $5,275,000$, or just $1.7 \%$ of the country's population 
(Center for Judaic Studies and Contemporary Jewish Life). Although the U.S. population has increased markedly, the number of Jews living in America has remained steady since 1970. Some scholars of Judaism attribute this population stagnation to intermarriage (Freedman 74).

In the United States, Judaism has three branches: Orthodox, Conservative, and Reform. Specific rules about intermarriage apply to each group. Orthodox and Conservative rules on intermarriage are comparably strict, whereas the Reform policy is more flexible. Orthodox Jews have a strong religious identity and oppose intermarriage outright (Hartman \& Hartman 47). Similarly, Conservative Jews do not recognize intermarriage as legitimate, although they tolerate intermarriage if the mix-married partner converts to the Jewish faith (Hartman \& Hartman 47). By contrast, Reform Jews formally recognize "patrilineal as well as matrilineal descent as sufficient to pass on the Jewish heritage" (Hartman \& Hartman 47). They do not enforce a policy against intermarriage, and Reform rabbis may perform interfaith weddings.

Jewish intermarriage has concerned scholars since the first Jewish settlers arrived in America in 1654 (McGinity 2). The 1930s marked a time when many sociologists became consumed with studying mixed marriages. The great "wave" of immigration from Eastern and Southern Europe to the United States led to this research interest, which continued into the 1940s and 1950s (McGinity 2). By the mid-twentieth century, scholars began to view intermarriage as a sign of assimilation in the United States. Jewish intermarriage studies have "focused on rates and factors leading to marriage between groups, characteristics of both intermarriage and those who intermarried, and marginal adjustments and outcomes" (McGinity 2). Scholars who see Jewish 
intermarriage as an index to assimilation consistently focus on four issues: romantic love, independence, concern for children, and ethnicity.

In The Jew Within: Self, Family, and Community in America, Steven M. Cohen and Arnold M. Eisen explain that many Jews in the United States "have turned inward in the search for meaning," no longer exhibiting loyalty to the Jewish tribe or collectivist ideals. Cohen and Eisen's portrait of the contemporary individualist Jew illustrates the first scholarly issue: independence. Cohen and Eisen conducted 50 in-depth interviews across the United States to learn about each subject's "Jewish development" in "his or her own words." The interviewees were chosen by the recommendations of "contacts in synagogues, Jewish Federations, Jewish community centers, or other agencies" (Cohen \& Eisen 4). According to Cohen and Eisen, "Nowhere is the departure from Jewish tribalism so vivid as in these Jews' attitudes toward intermarriage" (188). A personalist attitude that consumes many Jewish Americans today has led to an acceptance of intermarriage by Jews in the United States who feel no commitment to "traditional survivalist ideology or obligation to God or tradition" (188). Many modern American Jews now place greater importance on their individual independence than community, a “second language" for some Jews (Cohen \& Eisen 7).

Accompanying the rise of independence, an increasing number of American Jews consider themselves secular. For these individuals, Judaism is less religion than ethnicity. In the American Religious Identification Survey 2008, Barry Kosmin and Ariela Keysar say, "Over half of American Jews claim they have a secular outlook. Most of them see no contradiction between adhering to a religion and having a secular 
orientation." Contemporary American Jews with a personalist, secular outlook tend to approve of intermarriage (Freedman 25).

Freedman believes that secular Jews have separated ethnicity from religion through acculturation. He postulates that American culture and Jewish culture have become so interconnected that intermarriage is no longer forbidden, especially among secular Jews who associate only by ethnicity. Freedman says, "But once intermarriage is rampant, once bagels outsell doughnuts, once 'Seinfeld' is a hit even in Boise, then Jewishness as ethnicity, as folk culture, as something separate and divisible from religion, is ceasing to exist in any meaningful way" (25). Replacing religion with ethnicity opens the door for intermarriage.

A third contemporary influence on the choice to intermarry is romantic love. In Still Jewish: A History of Women and Intermarriage in America, Keren McGinity argues that Jewish women in the twentieth century chose their own path to marriage instead of following the traditional rules of Judaism. Through interviews with 43 women in the Boston area who intermarried, McGinity found that Jewish women who had no belief in God and weak ethnic ties married for love (65). They were able to "separate Jewish culture from belief in God, and their Jewish identities from their interfaith marriages" (McGinity 168). According to McGinity, "Western ideas about love and marriage infiltrated the shtetlekh (small Russian and Polish towns) and were reinforced among Jewish immigrant women in America; love, freely chosen, took precedence in the modern age over yichus (prestige) brought to one's family" (24). The old world no longer guided these Jews' choice about intermarriage; Jewish youth in America embraced the individualist ideal and began to intermarry with or without their parents' approval. 
McGinity's research subjects were examples of such women: "If an immigrant woman married for love rather than religion, as did all three of the women examined in this chapter, she exemplified an American ideal and therefore the zenith of acculturation" (24-25). McGinity says, "American interfaith romance, with its emphasis on individualism and personal happiness, had eclipsed the desire for any divine involvement in an increasingly secular American Jewish culture" (169). Irrepressible feelings of romantic love drove many Jewish women to choose intermarriage over religious tradition.

Jim Keen's auto-ethnography, Inside Intermarriage: A Christian Partner's Perspective on Raising a Jewish Family, discusses the intimate struggles of intermarriage: dating, life cycle events, parenting, and holiday celebrations. Keen, who decided not to convert and to continue to observe Christianity, highlights the struggles he and his wife faced when they decided to raise their children Jewish. He raises the issue of concern for children, the fourth scholarly issue, within intermarriage. Keen says, "To be honest, when Bonnie and I discussed the religion that our children would have before we were married, I wasn't sure that I could raise Jewish children - especially if it meant going through this coming-of-age ceremony" (71). Intermarriage shapes the way a couple will raise their children. Keren McGinity says, "[T]he more crucial question for people interested in Jewish continuity regarding intermarriage is not how the individuals involved identify but how their children were raised and what that would mean for the future of the Jewish people" (7).

In order to understand attitudes towards Jewish intermarriage in the United States better, this study examines Jewish websites and online discussion boards to see how 
romantic love, independence, concern for children, and ethnicity - the topics commonly associated with Jewish interfaith relationships and intermarriage - are discussed there. Discussion boards are utilized as forums to express opinion, emotion, advice, news, and other information about Jewish intermarriage. Specifically, this study examines conversations on two websites: interfaithfamily.com and joi.org. Interfaithfamily.com aims to provide "resources \& services for interfaith couples and families exploring Jewish life." Joi.org is "dedicated to creating a more open and welcoming Judaism." Narrative analysis of discussion board posts is used to characterize contemporary conversations about Jewish interfaith relationships and intermarriage by revealing patterns among the four topics outlined as scholarly issues.

Participants in discussion boards about Jewish interfaith relationships and intermarriage, for the most part, talk about issues in an interpersonal context. Early research on interpersonal relationships online found that they "are genuine personal relationships in the eyes of the participants" (Parks \& Floyd 82). The Internet enables individuals to interact on an interpersonal level because relationships are developed through dialogue.

The Internet allows users to communicate with a broad population of other discussion board participants. More than in face-to-face communication, online communication encourages hesitant individuals to talk openly. Online communication has thus become a resource for discussion about religion. Heidi Campbell comments on the importance of the Internet for religious discussions: "By the time of the publication of Time magazine's special issue on religion online in 1996, dozens of religious web sites and resources could be found online" (Campbell 311). The 1996 Time magazine article 
illustrated the importance of the Internet as a means for communication about religious topics. Time reported, "For many signing on to the Internet is a transformative act. In their eyes the web is more than just a global tapestry of personal computers. It is a vast cathedral of the mind, a place where ideas about God and religion can resonate, where faith can be shaped and defined by a collective spirit" (Chama 57). The increased use of the Internet fostered public discussions about Jewish interfaith relationships and intermarriage.

As Azy Barak and Orit Gluck-Ofri explain, a key concept for examining discussion board posts is self-disclosure: "This type of social environment is characterized by more open, straightforward, and candid interpersonal communication, a phenomenon explained by disinhibition effects" (408). Discussion board posts to interfaithfamily.com and joi.org contain self-disclosure about interfaith relationships and intermarriage. Many users begin their posts by revealing whether they are Jewish or not. Such self-disclosure opens a line of communication for others to join.

One site of online discussion about Jewish interfaith relationships and intermarriage is interfaithfamily.com. Interfaithfamily.com says that it "empowers people in interfaith relationships - individuals, couples, families, and their children - to make Jewish choices, and encourages Jewish communities to welcome them." In 2001, Edmund Case founded interfaithfamily.com as an independent, non-profit company and acquired the URL. Posts about Jewish interfaith relationships and intermarriage comprise more than three-quarters of the discussion board conversations on interfaithfamily.com. Among the score of discussion board headings on interfaithfamily.com are "interfaith marriage," "growing up in an interfaith family," "grand-parenting/parents of adult 
intermarried children," and "interfaith families and the Jewish community." The discussion board introduction tells users:

You do not need to join our Network to post to the discussion boards. However, joining the Network will give you access to a wide range of user options, including subscribing to email notifications about new discussion board threads and replies. In addition, members of our network can create user profiles, find professionals in the Jewish community, meet other people like them and much more.

This statement outlines the purpose of joining interfaithfamily.com. Those who choose not to join interfaithfamily.com are still able to post questions and comments in the discussion board. However, users who join the Network gain access to more features on the website as well as to community networking.

Another source for online discussion of Jewish interfaith relationships and intermarriage is joi.org. Joi.org describes itself as "an independent, national, transdenominational organization reaching out to unaffiliated and intermarried families, and helping the organized Jewish community better welcome them in." Users find a welcome statement before entering the bulletin board discussion page that says, "This section of our web site was created to provide a forum for dialogue among people who have a personal, emotional, intellectual or religious concern about interfaith issues affecting family and community." The first posts to the joi.org discussion board appeared in 1999. Posts about Jewish interfaith relationships and intermarriage make up a quarter of the discussion board conversations on joi.org. 
The present study seeks to answer the question: What do the conversations on relevant Internet discussion boards reveal about how individuals regard Jewish interfaith relationships and intermarriage today? Discussion board posts on interfaithfamily.com were analyzed beginning with the first posts in October of 2009 and posts on joi.org were analyzed beginning with October of 1999. These dates mark the starting date for discussion board posts on the websites. The last posts analyzed were from December of 2011. A total of 169 posts were analyzed. Text from discussion board posts were recorded and coded using the software program QDA Miner, which assists "data storage, coding, retrieval, comparing, and linking" of samples (Patton 442). The four topics that were identified based on the scholarly histories of Jewish intermarriage framed the narrative analysis of discussion board posts on interfaithfamily.com and joi.org.

Romantic love, the first topic, emerges as a point of discussion in a post on joi.org by Michelle 12867: "I've met a man who I have fallen head over heels in love with. I know what a gift it is to find this kind of love. I am catholic, he is observant Jewish." Michelle12867 expresses her concern for her interfaith relationship; her post goes on to describe her partner's unwillingness to marry based on her religion. Michelle12867 wishes to continue to observe Catholicism, whereas her partner who does not believe in intermarriage wants her to convert to Judaism. Their romantic love may not lead to intermarriage because of their strong religious commitments.

A post from user Chana on joi.org illustrates independence, the second topic identified as a scholarly issue pertinent to Jewish intermarriage: "I was raised a Torah observant Jew in a religious Jewish neighborhood. When I was in my early 20 s, I 'rebelled' and married a Gentile. He was originally of a Baptist background, but now 
practices no religion." Chana describes her Jewish affiliation as rebellious; the language in the post indicates that her independence made her open to intermarriage.

Concern for children, the third topic, is evident in a post on joi.org by Andrew: "I am in a similar situation -- agnostic (me) with Jewish girlfriend. We would get married tomorrow if we could clearly define what type of upbringing our kids would have. She wants them to be Jewish, I do not." Intermarriage for Andrew and his partner raises the difficulty of deciding how to raise children.

The following post by Tac on interfaithfamily.com exemplifies ethnicity, the fourth topic: "I don't really have the desire to be religiously Jewish, but I still feel that it's part of my identity. It's tough, though, since many wouldn't consider me to be Jewish at all, even further confusing things." Tac discusses her ethnic religious ties to Judaism and the internal struggle she has experienced when deciding how to raise her children. Raised in a secular Jewish environment and having a husband who was raised Lutheran, Tac did not feel that her religious ties to Judaism were strong enough to raise her children in the Jewish faith. Her post explores the line between ethnic and religious Judaism.

Jewish interfaith relationships and intermarriage is an ongoing topic of communication for rabbis, academics, historians, and many other community members. Researching Internet discussion boards is one way to gain access to conversations people are having. Analyzing online conversations about Jewish interfaith relationships and intermarriage can reveal individuals' beliefs and motivations. The conversions between interfaith couples is important to research because they reveal rationales behind interfaith relationships as well as subsequent reflections on experiences of intermarriage. 


\section{CHAPTER II}

\section{METHOD}

This study analyzed 169 messages posted to two website discussion boards, interfaithfamily.com and joi.org, in the spring of 2012. Both websites provide a discussion board for registered and non-registered individuals. Those who post on these websites seldom mention their age or socio-economic status, but they usually reveal their gender and whether they are Jewish or Christian. Jewish contributors seldom identify their branch of Judaism.

A general Internet search was conducted to determine relevant websites with discussion board activity about interfaith marriage. Interfaithfamily.com, joi.org, and religiousforums.com were selected because they seemed to have pertinent data about Jewish interfaith relationships and intermarriage. Upon further examination, however, religiousforums.com was deemed insufficient or irrelevant for this research study because it had too few posts that pertained to Jewish intermarriage. Removing religiousforums.com from the study left two relevant sites: interfaithfamily.com and joi.org.

Interfaithfamily.com offers 18 discussion board categories, all of which were examined for relevant cases. This procedure was conducted by examining each thread name to determine if the topic pertained to interfaith relationships or intermarriage. If a thread had relevant text, individual posts were examined. The names of the categories are as follows: Pregnancy, Birth Ceremonies and Adoption, 
Bar and Bat Mitzvah, Weddings, Death and Mourning, Passover and Easter, December Holidays, Other Holidays, Interfaith Marriage, Extended Family Relationships, Growing up in an Interfaith Family, Parenting, Interdating, Grandparenting/Parents of Adult Intermarried Children, Spirituality, Conversion, Interfaith Families, and the Jewish Community, Popular Culture, and Opportunities. Some categories, like Interfaith Marriage, contained many threads that were utilized for this study. Conversely, categories like Popular Culture contained no relevant threads. Within these individual discussion boards, on interfaithfamily.com, 102 relevant cases were found. Each case - one post in a thread - was saved as an individual document, including the user's screen or member name as well as the thread name and date of the post. Although many cases have the same thread name, they can be distinguished from one another because they were written by different discussion board users at different times.

Joi.org's discussion board contains only six categories, but its contents produced more relevant cases. The categories are as follows: Conversion, Family, Holidays, Life Cycle Events, Names, addresses, contact people, and Other. A total of 130 relevant cases were among joi.org's discussion board posts. Cases from joi.org were extracted and saved with the identical process that was used for interfaithfamily.com.

A total of 232 cases were loaded into the data processing program QDA Miner. After the entire data set was read twice, cases were coded by topic. Based on the literature review, the four topics for this study are romantic love, independence, concern for children, and ethnicity. As cases were coded, comments were written 
about the relevance of the topics to each case. Further examination of the comments led to 63 cases being discarded for irrelevance. Cases were eliminated if they did not contain significant issues about interfaith relationships or intermarriage or if they were too short. An example of a post that was not a significant issue concerning interfaith relationships is an individual who was seeking advice about what type of food to serve at her interfaith wedding. This winnowing left 169 cases for analysis in this thesis.

Fifty-nine threads, 169 posts, and 261 sections of text were coded and analyzed. In some posts, several codes were used accounting for the higher number of times coded versus total posts. For instance, one post may contain a code for ethnicity and independence.

To analyze the data set further, subthemes were developed. Subthemes were generated after examining each topic for reoccurring themes. The subthemes for the four topics are as follows:

$\underline{\text { Romantic love }}$

- pain - negative emotion caused by choice to intermarry or interdate

- strength - perseverance of interfaith relationship

Independence

- regret - unhappiness about intermarrying

- change - impending difference in life

- acceptance - interfaith relationship affirmed by family, friends, spouse, or significant other

- conversion - considering becoming Jewish 


\section{Concern for children}

- beliefs - importance of child's religion

- accommodation - agreement about child rearing

Ethnicity

- faith - place for religious belief in one's life

- religious traditions - religious holidays and celebrations

- observance - level of religious participation

- culture - association through community-based traditions

Qualitative data were analyzed according to the coding procedure that Carl F. Auerbach and Louise B. Silverstein describe in An Introduction to Coding and Analysis: Qualitative Data. First, the raw text was condensed to include only relevant text. The posts were kept based on their relation to the research concerns, or topics, for this study. Second, posts that contained similar words and phrases were identified and categorized by subtheme. Lastly, the text was organized into a narrative (Auerbach \& Silverstein, 2003).

Quotations were copied exactly as the individual posted them in the discussion board. Spelling, grammar, and diction were not changed. This detail has been disclosed prior to the results section in lieu of writing "sic" following each quotation. 


\section{CHAPTER III}

\section{RESULTS}

\section{Romantic Love}

Romantic love comprises $12.8 \%$, or 28 codes, making it the least discussed of the four topics. Romantic love is defined as an expression or connection to a partner that is based on emotion and desire. Both Jews and non-Jews are analyzed in this category. Romantic love is discussed similarly among all religious groups.

The first subtheme in the topic of romantic love is pain. It comprises $36 \%$ of codes about romantic love and was coded a total of 10 times. Pain is defined as negative emotion associated with an interfaith relationship or intermarriage. Many users discuss the pain they experience when their romantic love cannot sustain the difficulties associated with their interfaith relationship.

Charlie struggles with the pain of romantic love. As the Jewish partner in an interfaith relationship of which her parents disapprove, Charlie says, "Unfortunately this situation has become so difficult that it has reached the point where [I am] actively concealing the relationship from [my parents]." This concealment is painful for her because she feels deep romantic love for her non-Jewish partner. She loves "and [is] loved by, a non-Jewish man" (JOI_Difficulties).

The non-Jewish partner in an interfaith relationship, Michelle12867 endures

pain because her partner disapproves of intermarriage. Michelle12867 says, "I've met 
a man who I have fallen head over heels in love with. I know what a gift it is to find this kind of love. I am catholic, he is observant Jewish." Although she sees the obstacles, Michelle12867 also communicates the strong romantic love she has developed in the relationship. Because of that romantic love, she feels "crushed" when she finds out that her partner "feels interfaith marriages can't work." Despite her partner's negative opinions about intermarriage, Michelle 12867 feels an individual is "so blessed to find great love, anything is possible. HELP !!!!" Expressing the deep pain associated with the romantic love she feels for her partner Michelle12867 says, "I felt like I was kicked. Every time I try to walk away from him, I'm drawn back." Love, for Michelle12867, is both the source of her pain and the reason she remains in an interfaith relationship. In this case, pain is a result of her partner's unwillingness to consider intermarriage (JOI_I'm in love with a Jewish man).

In a separate post, Michelle12867 further discusses the challenges she faces. She struggles to balance the love she has found with the pain that has followed. Michelle12867 says, "I cannot begin to tell you how my heart is breaking over this issue. It's such a gift to find someone who you love on so many different levels. It's very difficult how he is so unwilling to compromise though." Caught between love and her partner's refusal to intermarry, Michelle 12867 is an example of an individual who experiences pain because of romantic love (JOI_I'm in love with a Jewish man). LaylaV is the Jewish wife in an intermarriage. Her husband is Catholic. She responds to a post from another user by saying, "I feel your pain literally." LaylaV says, "We are actually the most successful and happy couple/family in the group, and 
I always naively hoped my husband's happiness would persuade those who supposedly loved him to feel differently about me." She and her partner are not battling each other over intermarriage; rather, they attempt to convince her Catholic in-laws that their romantic love sustains their intermarriage. However, LaylaV endures pain because of the disapproval of her in-laws (JOI_In law problem).

Another Jewish partner in an interfaith relationship who struggles with the pain associated with romantic love is an individual called hsterman. Hsterman and her partner "really love each other and cannot imagine [their] lives without one another." However, hsterman is struggling to convince her parents that the romantic love she shares with her partner is all that matters; the fact that he is not Jewish is unimportant to her. Hsterman, in her post on joi.org, discusses the pain she endures: "my dad has never even met my boyfriend and refuses to do so only because he's not Jewish, and not only that he doesn't even acknowledge his existence. i have been depressed for quite some time but lately it has been getting worse, to the point where $\mathrm{i}$ have honestly begun to think that maybe $\mathrm{i}$ should not even be alive anymore if my father can't understand the happiness this guy brings me and how he is so willing to make specific sacrifices for me in terms of religion. i just don't know what to do anymore."

This case illustrates the agony sometimes associated with interfaith love (JOI_In tears).

In another post, hsterman further explains her frustration. She says, "I am tired of crying and screaming and breaking things. i feel so alone right now." Hsterman wishes she "didn't have to go through all of this pain and suffering just 
because" she is "in love." This quotation clearly illustrates the difficulty that can occur with interfaith dating. Hsterman endures the pain brought on by romantic love (JOI_In tears).

As a non-Jew in an intermarriage, Linda struggles to maintain the romantic happiness she originally had as an intermarried individual. Yet, after strains with her in-laws she is now "quite depressed" where she was "previously very happy." Linda asks the joi.org discussion board community if "this [is] just hopeless?" Throughout her post, the reader learns that Linda's romantic feelings have somewhat waned because of the pain she has experienced in her intermarriage (JOI_My mother in laws anguish).

Ruth makes a general comment about romantic love and pain associated with it: "It's very painful and very disorienting to have the kind of feedback you're receiving from your ex. Love should be a blessing and a gift, but sometimes it really hurts." This comment reiterates the intensity generated by interfaith relationships or intermarriage and the potential pain that stems from it (JOI_Knowing when to call it quits).

Unlike pain, strength represents hope for the endurance of an interfaith relationship. It is the second subtheme of romantic love. This theme makes up a larger portion of the total data set than pain. Strength was coded 18 times, and makes up $64 \%$ of the topic romantic love. Posts about strength, whether written by a Jew or non-Jew, communicate the individual's perseverance of intermarriage because of the couple's emotional bond. In spite of the positive effects of strength, some posts 
illustrate negativity. The negative aspects of strength represent uncertain feelings about the endurance of romantic love.

Emily is an example of positive strength. The non-Jewish partner in an intermarriage, she says that their "love is very strong." As a result of the strength she and her partner exhibit as an interfaith couple, they "have come to embrace" their differences. They "have a happy house where they encourage many forms of spiritual exploration and continue to enlighten each other." Emily and her partner see themselves as an intermarried couple that, through strength generated by romantic love, experience few difficulties (IFF_Unaccepting Inlaws).

Debbie B. enjoys similar positive aspects of romantic love. She and her partner intermarried long before she decided to convert. The romantic strength of this couple led to Debbie. B's desire for an Orthodox home. As the non-Jewish partner, Debbie B. trusted that the romantic love between herself and her Jewish husband would continue. Debbie B. says, "While I was studying for conversion I finally got up the courage to tell my husband that I wanted a strictly kosher kitchen. It was a true indication of his love for me that he agreed even though it was not something he had felt the need to do." The couple, although intermarried for years, gained romantic strength during Debbie B.'s conversion (IFF_My wife is going Orthodox on me in bits and pieces).

Another positive discussion of romantic love comes from $\mathrm{K} \mathrm{M}$ who believes that romantic love and the strength of her relationship have bound her to her partner. K M says, " $[\mathrm{F}]$ or the last six years my best friend and business partner and I have formed a very, very close bond." Having deep respect for his religious devotion she 
decided "that we were too fully emotionally invested in each other to be in successful relationships with other people so I was going to dissolve my partnership with him and move away, leaving him free of me to find his true path." But he refused to break up with her. She recalls, "He wouldn't let me and again, long story short, we're dating now." Aware of the difficulties of interfaith dating, K M and her partner, nonetheless, chose to move forward with their relationship. K M says, "[H]e's my bashert - I've believed in it since one of my best girl friends told me of the concept and I want to do what's right." $\mathrm{K} M$ defines her partner as her soul mate, whom she considers predestined or ideal. Having found her soul mate, she feels the strength of their relationship outweighs the difficulties of interfaith dating (IFF_One big complicated mess I just need a little advice guidance support).

Amelia03 is another non-Jewish partner in an interfaith relationship. Unlike $\mathrm{K} \mathrm{M}$, Amelia03 endures the negative aspects of romantic strength. She suffers because religious differences diminish her partner's commitment to her. Amelia03's partner refuses to marry her because of differences in religion. Amelia03 says she is "really confused because one hand he tells me he has such strong feelings for me and I'm the one for him, but he can't be with me because I'm not jewish." She struggles to understand why her partner, who has such strong romantic feelings for her, refuses to continue their interfaith relationship. Amelia03 says, "I'm not sure what to do? He fights to keep me in his life, but I'm not sure what for." This case demonstrates an emotional bond between partners that proves strength prevails as a unifying factor in interfaith relationships. However, strength does not provide hope for this couple (JOI Knowing when to call it quits). 
Alicia posts on the joi.org discussion board because she is confused. She and her partner experience the negative effects of strong romantic love because they are separated by religion. The Jewish partner in an interfaith relationship, Alicia explains that although she is not religious and does not go to synagogue, she does believe in God. Alicia goes on to describe her partner: "I have NEVER had such a wonderful loving relationship in my life. I have never been happier and he is the NICEST guy I have ever been with. He is so sweet and emotional." Alicia describes strong romantic love. However, Alicia says, "This entire religious situation reminds me of a Shakespeare play, when 2 people are so in love and can't be together because of uncontrollable forces, like in this case, religion." Alicia and her partner's differing religions have led to concern about their future as an intermarried couple. She says, "We talked in the past and he told me that he wants to be married in a church. He has always dreamed of his wedding to be in a Church, the one next to his mother's house. He was an Altar boy there and was baptized there as well. I feel very confused about all this, especially now that my mother has told me that she won't come to my wedding." She and her partner share romantic strength, but face interreligious obstacles (JOI children family).

Like Alicia, aqua19 struggles because she is Jewish and her partner is not. Aqua 19 says, "He is my idea of perfect except for one detail...he isnt jewish!" Aqua 19 and her partner are a strong match romantically, but they are of differing religions, an obstacle aqua19 is not sure she can overcome. In contrast to her friends' opinions about interfaith dating, aqua 19 believes that "G-d sent me this wonderful person and if I am intended to be with someone of Jewish faith that G-d will send me 
this person..." Struggling to decide if her partner is right for her, aqual 19

communicates that she "would be greatful for any information that you can offer!" In response to aqua19's request for help, caroline sympathizes and describes her own situation. After breaking up because of interfaith difficulties, caroline and her partner "realised that this relationship was special and truely important to both of us, and we are back together." Romantic love prevailed; caroline's relationship was strong enough to endure the difficulties of interfaith dating (JOI_dating).

A Conservative Jew who goes by $\mathrm{E}$ has found, contrary to his lifelong intent, a non-Jewish woman whom he wants to marry. E discusses what he believes to be positive and negative strength in a relationship. E says, "I never thought I would fall in love with someone who is not jewish. But unfortunately, or fortunately, I believe I have found someone that can make me happy forever." Despite the romantic strength E feels for his partner, he is conflicted because she is not Jewish. E says, "Here is my problem. I truly believe this girl is the one for me." E's confession of having found perfect love, yet wishing to deny it because of religious differences, illustrates the difficulties of interfaith dating (IFF_Jewish man and non-Jewish woman).

DDan1967 experiences similar positive and negative romantic strength. He is the non-Jewish husband with a Jewish wife. DDan1967 has "been married for a little over a year to a wonderful woman who was adopted from Southern America and raised Jewish by her mother, whom was a convert to Judaism herself." DDan1967's wife, who told him, "that I was the perfect man with the exception that I was not Jewish," has begun to attack his beliefs. He focuses on romantic strength. He says, "Nevertheless, I do not believe that two people in Love whom both have a strong 
belief in G_d are wrong." Despite the difficulties he faces as an intermarried nonJew, DDan 1967 stands by the romantic love he and his partner share (IFF_My wife is going Orthodox on me in bits and pieces).

A youth professional from Chicago posts to joi.org because he feels teenage interdating is a largely ignored topic. He poses a general question for the community, asking if the discussion board members have advice. Blisker says, "Many of our members are from intermarried couples, and we strive/struggle to find innovative ways to facilitate discussion on the topic. The standard talking points are 'if you love each other...' and 'nobody can tell you who you should love/marry,' which often produce heated but one-dimensional discussion." Blisker touches on the topic of romantic love. He writes that many intermarried couples choose to marry out because they have found strength in romantic love. One user responds to Blisker and writes, "I think there should be more posts about Jewish/ non-jewish dating because certainly that relationship could have used it." These two individuals identify a gap in communication about interfaith dating, particularly within the context of teenagers. Blisker goes on to write about the lack of communication at the time of adolescence and religious exploration. Before teenagers have a handle on their beliefs, they could have potentially found romantic love. Blisker believes "that the issue first arises...during adolescence -- religiously with bar/bat mitzvah, psychologically with the formation of identity, and emotionally with the beginning of relationships." Teenage interdating and strength of romantic love are topics of conversation in the joi.org discussion board. Discussing how young adults handle passion could open the 
door for further conversations about interfaith dating and marriage (JOI_teenage interdating).

Romantic love is an important topic of conversation. The two subthemes addressed in this section are pain and strength. Although both themes overlap, each contains important analytical components. Strength illustrates romantic love as both positive and negative reasons to intermarry, whereas pain represents only negative aspects of interfaith relationships. Some posts suggest that romantic love doubles as feelings of sexual desire. Individuals who believe their relationship is built on strength, at times, feel optimistic towards interfaith relationships. Conversely, individuals whose romance leads to pain most often feel discouraged about interfaith relationships or intermarriage. Either way, strength and pain are clear indicators that an individual has strong affection towards his or her partner. Romantic love comprises about an eighth of the total data set and is important for that reason.

\section{Independence}

Independence is a multifaceted concept in discussions of interfaith relationships and intermarriage. Regret, change, acceptance, and conversion all help to define independence as it relates to interfaith relationships and intermarriage. Some subthemes represent independence whereas others signify dependence. For example, an individual's parents may disapprove of intermarriage, however the individual still chooses to intermarry; this scenario signifies independence. Conversely, an individual who intermarries and later regrets the decision illustrates dependence. 
The first subtheme in the topic of independence is regret. Coded only six times, regret comprises $8 \%$ of codes about independence. Still, regret is an important subtheme because it defines unhappiness sometimes associated with intermarriage. Regret, a dependent behavior, is defined as users who communicate distress after intermarrying. Individuals in this subtheme display dependence and also express unhappiness about their decision to intermarry.

Marc Liberman expresses regret as an intermarried Jewish man. He says in his post on interfaithfamily.com, "I have been married to a non-Jew for 12 years and only started having regrets a few years ago. Usually it's a thought of 'if I could go back and do it all over again' or that if we were to ever get divorced, I'd be sure to marry a Jew the next time." Marc Liberman, although mostly happy with his intermarriage, says, "Some of it also has to do with disagreements over religious schooling, traditions, shul membership, etc. (despite agreements that we would raise a Jewish family) that make me think it would all be so much easier if I had just married a Jew." Marc Liberman is an example of a Jewish individual who demonstrates dependence because he regrets intermarrying. He says, "You'll always live with that regret and that question of "what if' floating around in your head" (IFF_Feeling guilty for not dating a Jewish guy Advice is welcome).

Aliza, like Marc Liberman, is the Jewish spouse in a long-term intermarriage. She regrets choosing to intermarry because "according to 'Jewish law' it is wrong." Aliza says she "can not do Tushuvah because I will not divorce my husband that I feel as though I was supposed to 'marry.' I feel like giving up -- I feel all alone." 
Aliza is dependent because she regrets her decision to intermarry and feels as though she is unable to practice Judaism fully (IFF_Give up or).

Tac's situation somewhat differs from that of Marc Liberman and Aliza. She is not religiously Jewish, but having a Jewish father ties her to the religion. Tac is ethnically bound to Judaism. Despite this attachment, she chose to marry a Christian man and regrets not developing Jewish customs in her marriage. She says, "I'm angry because I don't want to go to church and I don't like being guilted into it because my husband doesn't want to go alone. I'm angry because my family (and I) don't have any traditions of our own, so that I could at least feel like I had something that was my own. Also, I'm worried about the future and how having kids will deepen these feelings inside of me." Tac's explanation of how religion is observed in her marriage exemplifies her regret over not marrying in. Tac reveals that had she married a Jewish man, she might have been afforded the opportunity to observe Judaism in her family life (IFF_Not sure what to do).

Noidea, the non-Jewish partner in an intermarriage, has " 2 children with her Jewish husband." She is Christian. Noidea says that, before marrying, she and her partner never discussed how their intermarriage would affect their family. Noidea refuses to divorce, but she communicates her feelings of regret. She says, "I love my hub dearly and would never dream of divorce, I regret that we didn't iron out all issues prior to marriage." This post illustrates some of the gravity of intermarriage. Having not discussed their individual desires about religion and family in advance, Noidea and her partner subsequently faced unanticipated difficulties (JOI_raising children in both religions). 
Interfaith dating and intermarriage inevitably cause some aspects of a couple's life to change. The second subtheme, change, was coded 15 times and makes up $22 \%$ of codes about independence. Change is defined as a person who communicates a current or impending shift in family dynamics due to interfaith dating or intermarriage. Often, individuals encountering an interfaith relationship, whether their own or that of a family member, express anxiety surrounding an arrangement that will inevitably change. Change, as a subtheme of independence, is representative of both independent and dependent behaviors.

$E$ is a Conservative Jew who struggles with dating and possibly marrying a non-Jew. Commenting about his youth of Jewish observance, E says, "My entire life has revolved around jewish people (the sleepaway camp i went to for 14 years, $i$ was in a primarily jewish fraternity in college, all of my close friends are jewish, the neighborhood I've lived in all my life) and after dating many girls (all of whom have been Jewish), there is something that I feel is missing." $\mathrm{E}$ is contemplating change because he has found a non-Jewish woman with whom he has a strong connection. He says, "Before I knew it, I was already thinking about the non-jew more than my current girlfriend, prompting me to end my relationship." Although apprehensive about interfaith dating and intermarriage, E does not rule out the change he has brought into his life. He is considering "ending it with this girl because she is not jewish." Although E displays independent desires to break ties with his conservative Jewish upbringing, he also exhibits dependence concerning change. E's case reveals the anxiety brought on by change (IFF_Jewish man and non Jewish woman). 
$\mathrm{K}$ M's case is an example of dependence associated with change. She wants to convert to please her Jewish partner, but expresses apprehension about change. Although $\mathrm{K} \mathrm{M}$ is upfront about her intention to convert, change becomes an issue that inhibits her independence. $\mathrm{KM}$ understands that the change she invites is not necessarily a positive change for her partner. She remarks about this concern when she says, "As in - if I convert, I will need to be far more observant than he currently is and he doesn't want to change." K M's partner is apprehensive about discussing her conversion and "he still has not told his parents nor the rabbi." After recognizing her partner's anxiety, K M "reached a breaking point." She says, “[He] decided [their] relationship is good enough that he will" tell his parents and the rabbi about their relationship. $\mathrm{KM}$ and her partner face difficulties because of interfaith dating and change (IFF_One big complicated mess I just need a little advice guidance support).

For Rachel, change is also a test of independence. An observant Jew dating a non-Jewish partner, Rachel feels unease about her interfaith relationship. Instead of dating in, as E attempted, Rachel says, "I imagine that I will continue my journey of figuring this out." In response to Rachel's post, Andrea asks a series of questions to test Rachel's emotional commitment to an interfaith relationship, "Do you love him? Is there anyone Jewish around you'd love just as much? How old are you? How much time do you have to find someone else you love and want to have a family with? How will you feel if he cuts it off and marries someone else while you're dithering?" Andrea advises Rachel not to "marry him unless you can answer some of those questions honestly and feel good about what you're doing." Without a commitment 
to change, Rachel cannot fully embrace independence as a Jewish woman dating a non-Jewish man (IFF_Feeling guilty for not dating a Jewish guy Advice is welcome).

A third subtheme, acceptance, illustrates independence based on how others acknowledge an interfaith relationship or intermarriage. For example, a couple intending to intermarry receives disapproval from their family members. Should they choose to continue their plans to intermarry, their scenario is representative of independent behavior. However, if they choose not to continue with their plans they display dependent behavior based on their family's disapproval. Coded 16 times, acceptance makes up $24 \%$ of codes about independence.

A non-religious Jew struggles with how to tell her father about her engagement to an Episcopalian. Avib says her "parents know about [her] relationship and although they've never been supportive, they have come to accept it somewhat." Although Avib's mother accepts her engagement, her father expresses disapproval. Avib communicates her independence through her decision to intermarry (IFF_Breaking the news).

In response to Avib's post, an interfaithfamily.com discussion board member, Desiree, discusses her own story of parental acceptance. Desiree's experience differs from Avib's because she is a non-Jew desiring acceptance. After revealing their engagement, Desiree and her partner received discouragement from her parents. She says, "So my husband is jewish and when he and i first started dating my parents, mainly my father, were a bit hesitant about the whole thing." However, her father slowly began to accept her fiancé. Desiree says, "A few months before the wedding you could really tell that [my father] was excited about us getting married and was 
completely on board." This case portrays independence because the user continues with her plans to intermarry despite the initial disapproval of her parents (IFF_Breaking the news).

Acceptance often appears after an interfaith marriage occurs. For example, lgordon faced a difficult situation when he revealed to his Orthodox parents he would be marrying a Catholic. Sadly, the "father had a heart attack the next day" and disowned lgordon. But lgordon remained firm in his decision to marry out and "as time went on and they realized [he] wasn't going to change [his] mind they softened but were never welcoming to [his] wife." Lgordon did not receive acceptance prior to marrying his wife. However, with the addition of children to his interfaith marriage, lgordon's relationship with his parents evolved even further. He says, "When we had our daughter the s---t hit the fan again." Although he does not explain the religious choices he and his wife made for their daughter, lgordon communicates that his "wife became their favorite in-law and all of [his] siblings that married within the faith wound up divorced." Lgordon, in light of the tribulations intermarriage presents, exerts independence and his parents eventually come to accept his interfaith marriage. In this case, acceptance did not deter the individual's choice to intermarry (IFF Need support for being disowned).

Alaurie describes her own situation from an alternative perspective. Alaurie "has a daughter marrying a Christian." She says, "[I]t has been really hard to accept." However, Alaurie writes that her "daughter was more" important than a war over intermarriage. Alaurie's advice to Emily is to "explain that you feel hurt when you are treated like an outsider." This case demonstrates that not only is the couple 
entering into intermarriage forced to exhibit independence, parents must adapt, too. Alaurie's case demonstrates independence and acceptance from the perspective of a Jewish parent discussing her child's intermarriage (IFF_Unaccepting Inlaws).

Miriam explains her situation as the non-Jew with unaccepting in-laws. She remarks that her in-laws disapproved, but she and her husband remained independent. Miriam says about her in-laws, "[T]hey chewed me, but didn't swallowed me. But do you know what? My husband noticed that and he backed up from his family." After the death of her husband, Miriam's in-laws expressed their desire to rekindle a relationship. She says, "[Her husband's] brother and wife have been of great support to me, and [his brother] is very close with his nephews." Similar to lgordon, Miriam receives acceptance long after she intermarries; yet she remains religiously independent throughout her interfaith relationship (IFF_Unaccepting Inlaws).

Lauren struggles with acceptance from her boyfriend's parents. Her interfaith relationship of seven years garnered feelings of civility with her boyfriend's parents until they learned of his intent to marry her. Lauren and her boyfriend's parents do not accept each other: "When they are ready to at least respect me-I'll be ready to give them the light of day, but before a person is Jewish, Christian, Amish... whatever, we are all human beings, with feelings and dignity and the whole 9 yards?" But Lauren believes she cannot change their feelings towards her and her interfaith relationship. She says, "They have shut the door on themselves, and I will not spend another day of my life shedding tears and being anxious." Acceptance may be important to Lauren, but it is not something she is willing "to let them ruin [her] relationship of 7 years 
over." Lauren is displaying a strong sense of independence as a non-Jew struggling in an interfaith relationship (JOI_Trouble with in laws).

Sarah's in-laws displayed similar unaccepting behaviors. In response to Lauren's post, Sarah says, "My in-laws gave me the same party line... you're a nice girl, but you're not jewish, yadda yadda yadda...we don't go to intermarriages and we won't attend the wedding. And they didn't." Sarah remains independent as she continues to express positive feelings about her intermarriage. She does not waiver in light of her in-laws' outward unaccepting behavior (JOI_Trouble with in laws). Emily, a non-Jew marrying a Reform Jew, receives only negative comments from her in-laws and extended family. Emily says, "One point of marital contention is that the extended relatives clearly do not condone interfaith marriages (or therefore, accept me.)" Emily writes that their unaccepting behavior is often exposed in a passive manner. For instance, Emily says, "Most of the times, rude things are said in my presence but not directly to me." Intermarriage to Emily is not "the easiest path but discrimination continues to shock" and hurt her. She asks other users, "Do I stay silent and allow it to continue or do I start speaking up and asking harder questions? My husband is so sad to see me hurting but also doesn't know what to do. Our marriage is strong despite the harsh conditions, but I want to make the most of the time with my in-laws before avoidance becomes the only option." Not only is Emily facing unaccepting family members, she anticipates that she will no longer have a relationship with her husband's family because of her intermarriage (IFF_Unaccepting Inlaws). 
The final subtheme in the topic of independence is conversion. Among the users who post comments on interfaithfamily.com and joi.org, conversion was coded 31 times and makes up $45 \%$ of all posts about independence. Many Jewish interfaith relationships result in a Jewish conversion, lessening the strain within an interfaith marriage. Some partners feel pressured to convert but decide not to. Individuals who decide not to convert exhibit independence, whereas those who choose to convert to appease a partner, display dependence.

MJ, who had been married to a Jewish man for 28 years, discusses why she eventually decided not to convert to Judaism. She says, "I spent the first 6 months after my husband and I were engaged going to meetings with the Rabbi for conversion purposes." But MJ decided to remain Christian in an interfaith marriage, despite her in-laws' attempts to convince MJ to convert: "I was shocked that the view from my in-laws was it was not important I believe in their faith but that I convert, marry in the temple, and give them Jewish grandchildren." Although MJ believes that her in-laws "never cared or asked what [she] believed in," she nonetheless exerted her independence in her intermarriage (IFF_Married 28 years to Jewish man and children and I were never accepted).

Disapproval of an interfaith relationship is possible even if the non-Jewish partner chooses to convert after the couple is married. Gloweber decided to convert "very early in our relationship and even still, I can't say that I was welcomed with open arms." The decision to convert led Gloweber and Gloweber's partner to feel greater confidence in their relationship. "The opposition" forced the couple to develop a stronger bond. Gloweber's case is important because the language of the 
post describes the closed-door policy that pertains to Jewish intermarriage within some branches of Judaism. Gloweber exhibits dependence as the partner in an interfaith relationship that chooses to convert (JOI_Marriage divorce dating).

Michelle12867 states that she will not convert to please her Jewish boyfriend. She is "catholic, he is observant Jewish." Michelle12867 knew her boyfriend was Jewish when they became involved, but only after time did she realize "how observant he is." Her Jewish boyfriend communicates his wishes for her to convert, yet "that is not an option" for Michelle 12867. She is willing to compromise and raise their children Jewish, but she stands firm in her desire to remain true to her own religion even when her partner says that he will not marry her unless she converts. In this case, Michelle12867 displays independence when asked to convert to Judaism. Her case is important because conversion for one's partner is representative of dependence. However, Michelle12867 displays independence because she refuses to convert (JOI_I'm in love with a Jewish man).

In a response to Michelle12867's post, another user comments that if her partner is "opposed to interfaith marriage so strongly and knows your opinion about converting he puts you to unfair position by continuing the relationship." Carrot observes "converting really is not an option for you." Michelle12867 responds, "I would never convert my children, but I would expose them to the religion." She expresses strong sentiments about conversion and her adverse feelings towards giving up independence (JOI_I'm in love with a Jewish man).

$\mathrm{K} \mathrm{M}$ is in a relationship with an Orthodox Jewish man. $\mathrm{K} \mathrm{M}$ writes that as the relationship increases in intensity, she becomes more interested in converting to 
Judaism. Through conversion, $\mathrm{K} \mathrm{M}$ hopes to gain her partner's approval. $\mathrm{K} \mathrm{M}$ writes, "The only right thing to do to me, it seems, is to convert, so without him knowing, I enrolled in Judaism lessons taught by a Haredi rebbetzin online." She reveals to her partner her desire to convert and he decides "the relationship is good enough." Yet her partner still refuses to tell his parents about their relationship. KM displays dependence. Her plan to convert does not convince her partner to tell his parents about their interfaith relationship (IFF_One big complicated mess I just need a little advice guidance support).

K M does not advocate intermarriage. She writes that she understands "why interfaith dating/marriage is a bad thing." K M says, "I believe its reasons and have defended his faith for years before we were dating." Converting shows that K M is dependent. She leaves her Catholic heritage to lead a separate life as a Jew only for the approval of her partner. She reaches out to others in the discussion board on interfaithfamily.com because she has "no one to talk to who is going through this." Unlike an independent Jew considering intermarriage, $\mathrm{K} \mathrm{M}$ is a non-Jew who is dependent because she disregards her own wishes and continues to consider conversion. Dependence through conversion is seemingly a capitulation to the Jewish partner (IFF_One big complicated mess I just need a little advice guidance support).

Sometimes the parents, not the partner, push the non-Jewish partner to convert. The parents of Scramblepop's fiancée insist he convert to Judaism, but he struggles to maintain his independence. Conversion in this case is not an exhibition of religious enlightenment; it is a demand from an outside influence. Scramblepop begins his post by saying he is "engaged to a wonderful woman who happens to be 
Jewish." He establishes that even though his fiancée is wonderful, her parents "are pushing [him] to convert to the extent that it has driven a wedge between [them]." Scramblepop and his partner, before discussion of conversion, were cohesive. Yet Scramblepop's post indicates that his fiancée's father has put her "in a position where she effectively needs to choose between them and me." Scramblepop's fiancée, although Jewish, chooses to marry out. However, her parents object to her choice and push Scramblepop into a "conversion for cultural reasons" (JOI_Future Jewish inlaws help).

\section{Concern for Children}

A third topic is concern for children. Coded 74 times and making up $26.9 \%$ of the total data set, concern for children is defined as language that expresses worry or anxiety about actual or potential children in an interfaith relationship or intermarriage. Cases include conversation about the development of children, their connection to Judaism or another religion, and their growth as adults. Individuals write about their own children, their grandchildren, or friends' children. This topic is divided into two subthemes: beliefs and accommodation.

The first subtheme in the topic of concern for children is beliefs. This theme is defined as important aspects related to raising children in an interfaith family. Beliefs indicate where the individual stands with regard to child rearing. The subtheme of beliefs make up $47 \%$ of codes about concern for children and was coded a total of 35 times. 
Marc Liberman says that if he had married a Jewish woman, he would not struggle to employ his beliefs as a parent. Marc Liberman discusses how his beliefs have affected his life as an intermarried father. He says, "Some of it also has to do with disagreements over religious schooling, traditions, shul membership, etc.

(despite agreements that we would raise a Jewish family) that make me think it would all be so much easier if I had just married a Jew." According to Marc Liberman, the lives of his children would be different had he chosen to marry a woman who shared his religious beliefs (IFF_Feeling guilty for not dating a Jewish guy Advice is welcome).

Jenny's case is another example of an interfaith couple expressing concern for their children's beliefs. As the Jewish partner in an interfaith relationship, Jenny believes her future children should share her Jewish identity. She writes about a conversation with her partner pertaining to child rearing. Jenny says,

The discussion soon turned to children, with me explaining that even though I was not religious in the slightest, and had no intention of keeping kosher or going to shul, it was important to me that my children have a sense of Jewish identity. I don't want them growing up with a huge chunk of 'me' missing, knowing nothing of their history or family. I want them to learn hebrew and the various festivals and customs, so that if they ever want to be religious Jews they can.

Jenny explains her desire to pass on Jewish traditions, what she believes to be important for a child's religious development, to her potential children. However, Jenny's boyfriend "stated that he does not want any religion imposed on his children 
until they are old enough to choose for themselves." Jenny and her boyfriend's beliefs differ (IFF_I'm Jewish My Boyfriend Isn't).

Andrea2 gives general advice about raising children in an interfaith relationship. She discusses the importance of strong beliefs about religion. Andrea2 believes a couple should have a plan in place before child rearing begins. She says the children benefit if the interfaith parents "are comfortable with what [they] believe and how [they] want to raise any future children." Andrea2's advice signifies that some individuals are discussing concern about beliefs. Jewish and non-Jewish individuals communicate about beliefs because they place importance on concern for children (IFF_Not sure what to do).

The non-Jewish partner in an interfaith relationship, SueSmith talks about her husband's religious concerns about child rearing. SueSmith says, "He believes that is we raise the children with both religions, the christianity would take over becasue it is so evident in our society." Concern for children is a topic of conversation between SueSmith and her partner. Unlike her partner, SueSmith believes her children should be raised to observe both Judaism and Christianity. She wants her "children to understand [her] background as well. They will be half jewish and half christian. They should understand both." SueSmith's concern about children's beliefs are an important topic of conversation as an intermarried individual (JOI_children family). As a non-religious individual, Andrew writes that he believes his potential children should be raised with cultural Jewish traditions, not religious:

I don't want my children to be jewish, but of course they should recognize the cultural inheritance that a jewish mother will bring to a family. I don't care 
that some ancient biblical/Torah text is telling me - whether my children will be jewish or not. I want my children to be happy, fullfilled, to acknowleged the spirituality inherant in all of us, and above all, to see beyond the hypocrisy and self-rightousness that religous groups have wrought on this earth.

Andrew does not believe in religious traditions. He says that tradition, not religion, should be preeminent in child rearing (JOI_children family).

Accommodation, the second subtheme, makes up 53\% of all codes about concern for children and was coded 39 times. Many posts contain conversations about interfaith couples coming to an agreement about raising children. More often than not interfaith partners discussing their children or potential children consider the negotiation of religious preference for the children.

Pikachiu 132 is a Chinese woman married to a Jewish man. She discusses the decision she and her husband made pertaining to their children. She says, "For me it means doing the same things his parents do. Celebrating the high holidays, staying somewhat kosher (no pork, no dairy+meat at home) (and I do this only in their household) and occasionally celebrating Shabbat. I'm totally okay with doing that, as he is celebrating Christmas and Chinese New Year." Pikachiu132 explains that bringing up children in a Jewish home means following the traditions of her husband's family. The post is about accommodating a spouse (IFF_Breaking the News).

Rachel is the Jewish partner in an interfaith relationship. Although her boyfriend is amenable to the idea of raising children in the Jewish faith, she still feels "this cloud of guilt hanging around [her] for not dating a Jewish man. [Her] parents 
adore him and have no problems with him not being Jewish but for some reason [she] can't shake it." Despite her own reservations, her partner is "committed to raising any future children in a Jewish setting." Her boyfriend has accommodated her by agreeing to raise their potential children Jewish, however, Rachel struggles to accept the interfaith relationship (IFF_Feeling guilty for not dating a Jewish guy Advice is welcome).

In response to Rachel's post, a user called In the Same Boat writes that she does "worry that while [her partner] agrees to raise Jewish children now, this may translate into conflict later." In the Same Boat goes on to discuss the way her partner has been accommodating. She says, "I think being clear to yourself and your partner about what you can and cannot compromise is key. I have been very honest about these things in my relationship and my partner has been very accommodating (for an atheist!)" (IFF_Feeling guilty for not dating a Jewish guy Advice is welcome).

David Cohen also responds to Rachel's post. He writes that he is the Jewish partner in an interfaith relationship with an Asian woman. The partners accommodate each other in this case. David Cohen is divorced from a Jewish woman and they had no children. Now that he is in an interfaith relationship, he and his partner are faced with how to raise the children they may have together. David Cohen writes that his partner has accommodated his requests:

And should I really marry the wrong woman just because of the "Religion of the children is set by the mother" thing? Should my happiness be held hostage in that manner? Should I suffer in a mediocre or potentially vitriolic relationship, just because I feel this guilt? I've tried relationships with Jewish 
women, and I was even married to one (We agreed to have children before married, but 1 year into our marriage she decided Children do not work out into her future...!). So I decided to swallow this guilt, and that my children will be made aware of their Jewish roots, will be circumcised, and learn Jewish philosophy, despite the mother not being Jewish. My Asian girlfriend doesn't mind, in fact she seems interested in Judaism, and even offered to convert.

This example of accommodation shows how a couple has reached agreement (IFF_Feeling guilty for not dating a Jewish guy Advice is welcome).

The Jewish partner in an intermarriage, Zohar gives advice to another interfaithfamily.com discussion board member. Concerning children and accommodation, Zohar says, "I would recommended that you will figure out what is it that you would want to give your future children, and then talk to your partner and find a middle ground where neither of you gets all you want but you both can live with." She advises the individual to determine why her partner resents "the idea of his children growing up Jewish, what is the root of his feeling towards religion, so that he can later realize what he would like to give his children." Reaching a level of accommodation, according to Zohar, is important because it will ultimately determine the religious environment that the children will share with their parents (IFF_I'm Jewish My Boyfriend Isn't).

Steve is another individual who discusses accommodation. He is the nonJewish partner in an interfaith relationship. He writes that he is willing to accommodate some of his partner's religious desires, but he also wishes to retain 
some of his own traditions. Steve says, "[I have] no desire to raise my kids as Catholics, but I do want to participate in the secular versions of the catholic holidays (christmas, maybe easter... if only for the chocolate). I am willing to concede more for the right person (and she feels like the right person) but there are somethings I would like to continue." He writes that accommodation is possible with the right partner, whom he believes he has found. For Steve, interfaith dating represents adaptation (IFF_Interdating and interfaith marriage What does the future hold). Anonymous posts advice about accommodation. She says, "My husband is Jewish, I am Catholic. Over the course of our dating we discussed religion at length, we attend each other's services and support the religious journey each of us is on. We made a joint decision of how faith would be practiced in our home and that of future children." After exploring religious individuality, Anonymous and her partner decided to compromise about the rearing of their children. Anonymous goes on to write that resolving decisions about children makes dealing with family much smoother. She says, "When you have had the discussions, made the decisions and understand the faith of your partner and where they stand it makes the difficult discussions with family and friends much, much easier." Accommodation, for Anonymous, made intermarriage simpler (IFF_Interfaith marriage planning).

Jewish partner Rebecca seeks advice about children in intermarriage. She has come to an agreement with her boyfriend concerning the rearing of children. Accommodation is already a point of discussion with her non-Jewish boyfriend. She says, "Additionally, the conversation as led to a sort of 'compromise,' incorporating both religions into any future children, although I know from my own experience as 
well as from so many others, that choosing one religion to raise the children, but with respect and awareness of the other, is usually so much better for them." Because Rebecca understands the gravity of raising children in an intermarriage, she and her boyfriend determined in advance the most appropriate way to incorporate religion into their child's life (IFF_Interfaith marriage planning).

Like the other individuals in this section, Hannah understood that child rearing could present problems in intermarriage. When she discussed her concerns with her partner, he assured her that he would accommodate her when it to their child's religious upbringing. Hannah explains the basis of her interfaith relationship: "I was hesitant to start dating him because I foresaw 'religion issues' down the road, due to the fact that I want to raise my children Jewish when the day comes. I voiced my hesitations. He reassured me that that was fine, and I didn't have anything to worry about, and he'd be accepting of what I wanted to do religiously. So, we started dating." Although Hannah and her boyfriend share concern for children, they resolved religious difference through accommodation (IFF_Talking to my boyfriend about Judaism).

Margot's non-Jewish boyfriend is supportive of her desire to raise Jewish children. She says, "He respects and accepts my desire to have a Jewish home and raise Jewish children, and in this sense, this is not a typical 'interfaith' issue, unless the two faiths are Jewish and agnostic. He is not only supportive of raising Jewish children, but enthusiastic." Margot and her partner agree on a simple accommodation for children (JOI_What do you all think). 
Tac is the Jewish partner in an intermarriage. She says that she "ended up agreeing to allow [her Lutheran husband] to handle most of the religious education of our children, because a. I don't feel comfortable establishing my own Jewish traditions, since my family didn't have many and b. I don't feel comfortable going to church and participating in those customs. However, I'm now starting to feel very uncomfortable with this (we don't have kids yet)." After agreeing to accommodate her husband's desire to raise their children in his religion, Tac feels she has sacrificed too much (IFF_Not sure what to do).

In response to Tac's post, Anne Jones discusses her own situation. Unlike Tac, Anne Jones is the non-Jewish partner. Before the arrival of children, she and her husband also made concessions about child rearing. Anne Jones says, When we were dating, neither of us was religous so I didn't care if our future children were Jewish. Once I got pregnant, my feelings changed quite a bit. I went back to Church and felt strongly I needed to raise my children as Catholics. It's not because I became a devout person who attends daily mass. It's just that I had something I wanted to pass on to my children. The thought of watching my chidren have bar mitzvah's instead of first holy communion was heartbreaking to me. My husband is not religious and he agreed, but it was very painful for him and his family. We survived, but I have to say there will always be scars.

Accommodation does not always lead to happiness. For Anne Jones, it caused anguish and unhealed wounds. Interfaith couples may accommodate each other because they are unable to see clearly what they want for their children. Anne Jones 
is an example of an interfaith partner who agreed to accommodate her partner early on in her marriage, but regretted it later (IFF_Not sure what to do).

Similarly, Frank and his wife discussed the religious upbringing of their potential children in advance of starting a family. He recalls, "Before we had the first of our three children I agreed to raise the children Jewish under the premises that they know their father's upbringing." Despite the initial accommodation he and his wife made, Frank says, "since the birth of our first son my feelings have changed." Again, agreeing to accommodate a partner early in an interfaith relationship does not always end well (JOI_Interfaith marriage).

Emily01 is the non-Jewish partner in an interfaith relationship. Emily01 writes that she wants her children to have the opportunity to embrace her Jewish traditions as well as her future husband's. Emily01 says, "Our future children will be raised Jewish and we will celebrate only Jewish holidays. Coming to this decision was difficult and sometimes I do feel like I am giving up so much, not really a religion, but family traditions." Accommodation, for Emily01, is about sacrifice. She says, "[I feel] sad sometimes when I think that my children won't enjoy the same things I did when I was growing up." Although Emily01 discusses accommodation, she also reflects on the unease she feels with the decision she made (IFF_Interdating and interfaith marriage What does the future hold).

\section{Ethnicity}

Ethnicity is the final topic analyzed. It was coded 91 times and makes up the largest topic, or $34.1 \%$. For the purpose of this study, ethnicity distinguishes 
religious Jews from cultural Jews. Ethnic Jews may associate with Judaism through family history. The subthemes - faith, religious traditions, observance, and culture highlight the struggle individual's face when self-identifying as Jewish, yet wishing to intermarry. Many posts include descriptions of an individual's family history. For example, an individual may disclose that his or her mother is Jewish, but his or her father is Christian, and Judaism was never observed in the household. In this circumstance, the individual might associate with Judaism through ethnicity, but not religion.

The first subtheme in the topic of ethnicity is faith. Faith comprises $20 \%$ of codes about ethnicity and was coded 18 times. Making up the smallest percentage of subthemes in the topic of ethnicity, faith is defined as the place for religious belief in one's life.

DSarah has strong faith in Judaism, but her partner does not. They agreed to make Judaism the focus of their lives. Faith, for DSarah and her partner, means participating in certain religious activities that coincide with Judaism. DSarah describes her interfaith situation: "I'm Jewish, and my Catholic boyfriend (he was raised Catholic, and fell out of faith just a few years ago) has agreed to raise our kids Jewish because he'd rather raise them within a faith." Interfaith dating, in this case, is strengthened because of DSarah's commitment to a Jewish lifestyle (IFF_Interdaing and interfaith marriage What does the future hold).

DSarah's comment is in response to another user, Emily01, who posts about faith. Emily01 is "willing to give up some of [her] own family traditions in order to support him in his faith." Emily01 is the non-Jewish partner in an interfaith 
relationship. Her boyfriend's "faith and culture are an integral part of his life and they have made him who he is and who [she] love[s] today." Faith, for Emily01, means altering her lifestyle to embrace her partner's religious beliefs. That said, Emily01 posts on interfaithfamily.com's discussion board because she feels concern about losing her own faith in the future. She asks, "What if I change my mind 10, 15, 20 years down the road? I love my boyfriend and can't imagine my life without him, so these are things that I am still willing to give up." Religion plays an integral role in Emily01's interfaith relationship (IFF_Interdating and interfaith marriage What does the future hold).

Joe wants to integrate religious faith into his relationship. As a Catholic, he wishes to compromise with his Conservative Jewish girlfriend, but finds difficulty in doing so. They "have attended a course for interfaith couples and have had hours upon hours of discussions about [their] respective faiths." How faith will affect their "potential children" looms large for Joe. The couple, with their own ethnic individuality, struggles to embrace faith because Joe's parents disapprove of the relationship. Joe discusses what ethnicity means to both he and his parents: "In part, I think they fear for me. They fear that in not returning to live in my hometown (which, pre-relationship, might have been my intention) and in not raising my kids as Catholics (which, pre-relationship, would have been my intention) I am suppressing my true self and am making concessions that I will live to regret." Interfaith marriage is not an acceptable option and Joe is undecided on embracing his girlfriend's faith. In this particular case, the couple is struggling with the prospect of intermarriage because of their respective faiths (JOI_Please help this Catholic Jewish couple). 
Rather than seeking assistance, some individuals post in the joi.org discussion board to offer advice. EBP2 discusses the importance of faith in a religious or nonreligious intermarriage. According to EBP2, the level of faith the couple brings to the marriage determines the success of the relationship: "It matters inasmuch as you are religious. the more religious either of you are, the more impossible the situation becomes. if you really dont care that much, it won't affect either of you, but your children will probably not be religious." EBP2 remarks on the difficulties of growing up in an interfaith family: "I am a product of an interfaith marriage and it continues to be an awkward spot in the family even though the youngest sibling is now 27." The degree of faith that the couple brings to the interfaith relationship, according to EBP2, will establish the success of the couple (JOI_Interfaith relationship).

A second subtheme in the topic of ethnicity is religious traditions. The subtheme was coded 19 times and makes up $21 \%$ of codes about ethnicity. Religious traditions are defined as an individual's past, present, and future involvement in religious events. One example is participating in religious holidays or celebrations.

David Barak believes religious traditions coincide with his decision to respect the Jewish holiday cycle. Religious traditions can hinder communication in interfaith relationships. If a non-Jewish partner chooses not to acknowledge religious traditions of Judaism and its tenants, then the couple might face difficulties. David Barak explains what religious traditions mean to him as a Jewish individual: "As a Jew, I notice that my values are Jewish, and my schedule follows the Jewish holiday cycle, and that my identity is thoroughly wrapped up in 'being Jewish." He clarifies that 
his interpretation of Judaism is "as a religion foremost - unlike many who view Judaism as cultural or ethnic" (JOI_interfaith marriage).

Girlie struggles to connect with her boyfriend's parents. As the non-Jewish partner in an interfaith relationship, Girlie struggles to understand the importance of her boyfriend's Jewish traditions. She writes that her partner exhibits certain values, but she is unable to determine if they are religious or not. Girlie says, "There are times when my boyfriend talks about certain things being consistent with Jewish values. At times I am unclear to what degree he is truly speaking about universal Jewish values versus the personal values he has formed over the course of his life." Girlie communicates, through a description of her partner's religious traditions, strong trepidation concerning her interfaith relationship (JOI_Boyfriend's parents).

Hsterman is the Jewish partner in an interfaith relationship. She and her nonJewish boyfriend "share many common interests and values." Hsterman's religious traditions present an important topic of dialogue for the couple. Hsterman explains that Judaism is central to her life and that she and her boyfriend "are so alike in so many ways, save one...i am Jewish (non-Orthodox), he is not. my boyfriend is a nonpracticing Christian who hails from a very non-religious family." She explains that her partner is sensitive to her Jewish traditions and "he knows that Judaism is important to me and feels it is important to know about it so he can understand it better." Hsterman's ethnic ties, and religious traditions in particular, are important to her. However, she goes on to discuss in a subsequent post the difference she sees in the types of Jewish traditions. For instance, personal values, not tied to Judaism, have caused former relationships to fail. She says, "I've dated Jewish and non-Jewish men, 
and religion has not been the reason for these breakups. incompatibility in personality and interests merged with constant criticism and lack of open communication have caused the splits." Hsterman is an example of an ethnic Jew who embraces Jewish religious traditions, yet struggles to be secure in an interfaith relationship. Regardless of her partner's traditions, Hsterman believes her own religious traditions are crucial for the success of her interfaith relationship (JOI_In tears).

Observance is the third subtheme in the topic of ethnicity. This theme is defined as a Jewish individual's level of religious participation. For example, an individual who was raised Jewish and attended services but fell away from Judaism as an adult might be more inclined to interdate or intermarry. This subtheme is divided into two sections: those who observe the Jewish religion and those who do not. Observance was coded 24 times and makes up $26 \%$ of codes about ethnicity.

A product of intermarriage, Jenny was raised to observe Judaism in the community but not at home. Jenny describes her religious upbringing: "My grandparents on my mother's side are quite religious, and so although my home life never felt 'jewish', my school and family life did." This detail is important because Jenny's observance will ultimately determine how ethnicity surfaces in her interfaith relationship. Jenny explains that "it's not a choice, that you're a Jew whether you practise or not, he just didnt seem to understand." Although she states that it is important for her partner to appreciate her religious observance, she remains skeptical about intermarriage (IFF_I'm Jewish My Boyfriend Isn't).

Lora Hirshberg "was rasied observant." With one partner an observant Jew and the other a non-Jew, Lora Hirshberg states that interdating can be a struggle. She 
takes the initiative to "take an interfaith counseling class at the JCC" with her partner. Lora Hirsberg states that the class "allows for many of these discussions to take paret and gives you the opportunities to listen to other couples." Partly because the couple takes it upon themselves to seek help, observance is not the crux of this interfaith relationship (IFF_Jewish Woman Catholic Man HELP).

Sometimes a Jewish individual in an interfaith relationship stands to become more observant based on the religious interest of the non-Jewish partner. Charlie, for example, is "a young woman from a fairly secular Jewish family." Although her family disapproves of her interfaith relationship, she feels her "interest in Judaism and willingness to observe has been greatly increased by being with" her non-Jewish partner. Charlie's parents disapprove of the relationship "solely on the grounds of [their] religious differences." Charlie's level of observance, although a solid point in her interfaith relationship, is not enough to satisfy her parents. However, the interfaith relationship has the ability to succeed based on Charlie and her partner's willingness to compromise (JOI_Difficulties).

Chana posts on joi.org to determine if her feelings about intermarriage are hypocritical. The Jewish partner in an intermarriage, Chana is now pressuring her son not to marry out. She asks the joi.org community if this emotion is inappropriate considering her own situation. Paul responds with the following advice: "There have been studies that show a majority of Jews go through various degrees of engagement and disengagement with Judaism through the course of their lives. If the community had written you off forever when you intermarried, it would have been the community's loss because you went ahead and created an observant home and raised 
strongly-identified Jews." In spite of Paul's positive comments about levels of observance and the effect the have on decisions to intermarry, Chana opposes marrying out. Chana taught her "kids that intermarriage is a major no-no in traditional Judaism." She believes this despite that fact that "their father is not Jewish (I married him at a time when I was not religious)." Chana persists in believing that intermarriages produce non-observant families, despite her example of the exact opposite. Her ethnicity works against intermarriage in this case (JOI_Is this hypocritical).

HD is engaged to a non-Jew and admits that she is "scared." She explains that her minimal level of observance has already begun to affect her interfaith relationship. With two sisters who married in, she fears that holidays and child rearing will become strenuous. Observance works against the couple. In other words, HD wants her religious observance to influence her interfaith family, but finds it difficult because she was not raised in a particularly observant environment. HD communicates that her feelings exist because she "was raised reform and never had a Bat-Mitzvah." HD's case is an example of lack of observance creating strain in an interfaith relationship (IFF_Jewish Woman Catholic Man HELP).

Jamiert's "[M]om is Jewish and dad was catholic before he converted to Judaism before he married [her] mother. She "grew up in a small town and never really practiced Judaism." Jamiert and her Muslim boyfriend intend to marry and she is "happy being non-religious and [is] fine with the kids being Muslims and learning all religious knowledge from Daddy." Jamiert respects "all religions, but was never 
interested in being religious." For that reason, intermarriage for Jamiert and her partner is based on her non-observance (IFF_Me a Jew Him a Muslim Help).

Mandie, another interfaithfamily.com user, advises Jamiert to remain nonobservant. Mandie says, "If I were u...find out ur passion in religion, study in them. Then $u$ will know ur true ID...and then $u$ will truly know what $u$ want in ur future." Since Jamiert did not enter an interfaith relationship with strong religious observance, only cultural ties, her case is an example of how ethnicity affects intermarriage (IFF_Me a Jew Him a Muslim Help).

The fourth subtheme in the topic of ethnicity is culture. Culture applies to individuals who are not religiously Jewish, but instead associate through community affiliations. This subtheme was coded 30 times and makes up $33 \%$ of all codes about ethnicity.

As a Jewish woman dating a non-Jewish man, Rachel struggles with her interfaith relationship and feels unsure about change. In addition, Rachel also identifies as an ethnic Jew who is culturally affiliated. Rachel places importance on cultural ties, so she feels unsure about dating a non-Jewish man who might not understand "the Jewish culture and the things [she] did as a child growing up in a Jewish community." ANRK advises Rachel to refrain from intermarrying: "Don't marry him. You have too many reservations and are too tied to your cultural background. You admit to feeling jealous of other Jewish girls marrying Jewish men. Those feelings are unlikely to go away, no matter how hard you tell yourself they will." Through the language in Rachel's first post, ANRK detects that Rachel feels her cultural ties to Judaism rank high in her opinion about who to marry. ANRK goes 
on to comment on his/her own marital situation: "We have reached a happy median in our married life where neither cultural background is given greater importance than the other." Although ANRK speaks highly of his/her own situation, the advice he/she gives to Rachel follows more conservative lines. Because Rachel worries that intermarriage will cost her cultural ties to Judaism, ANRK advises her not to continue in her interfaith relationship (IFF_Feeling guilty for not dating a Jewish guy Advice is welcome).

Jenny identifies as Jewish, but not religiously. In her post she defines how she classifies her Jewish identity: "I feel that although I'm not religious, if $i$ ever wanted to be I would know how. And everywhere I go, that sense of community and belonging is something I wouldn't traid for the world." Judaism, not as a religion, but rather as a culture is important for Jenny. She expresses this point when she says, "I think what I'm asking is (through all this rambling) is that I need a way to show him that Judaism is more than a religion." The basis of Jenny's communication is expressed in last line of her post. She says, "can anyone advise me on how to make him see its the cultural and historical side of it I want for my children?" This case highlights the dichotomy between religious and cultural Judaism (IFF_I'm Jewish My Boyfriend Isn't).

Another case that expounds on the subtheme culture is in response to Jenny's discussion about interfaith dating and Jewish ethnicity. Zohar has "always defined [himself] as a cultural Jew - cause just as you said I am not sure I believe in God." Like Jenny, Zohar places importance on her cultural ties to Judaism and believes "in the importance of a community and tradition and the shared history of the Jewish 
people." Zohar relates to Jenny's situation because she is married to a Christian. She wonders if her own Jewish culture will survive if her husband does not convert to Judaism. Although Zohar is not religious, she is connected to Judaism through culture (IFF_I'm Jewish My Boyfriend Isn't).

London visits the interfaithfamily.com discussion board to ask for advice about her sister. The sister, a non-religious Jew, plans to marry a Hindu. The Jewish parents believe that London's sister's Jewish culture will diminish as a result of their daughter's intermarriage. Religion is not the concern for London's parents; they worry about combining cultures with different foundations. London's parents state their concern "about the 'culture clash' between Judaism and Hinduism and what identity the children will have." Intermarriage poses difficulties for couples that have separate cultural identities, yet choose to build a common life together (IFF_Sister is in interfaith relationship parent are distraught).

Debbie B., a frequent commentator on interfaithfamily.com, discusses the difference between religious and cultural affiliation. She explains that Judaism places importance on both doctrine and community, so that Jews feel a cultural pull even if they are not religious. Debbie B. explains:

The confusion about Jews who identify culturally more than religiously is due to the fact that unlike Christianity, Judaism has both a Peoplehood and a Religious aspect. Before we got married, when my husband told me that being Jewish was in some way more similar to being Chinese than Protestant, I didn't believe him. Fast forward 30 years: I now understand what he meant and think he was right. 
Debbie B. says that even if an individual was not born Jewish, like herself, he or she can still identify with Judaism on a cultural level. "Peoplehood" is used as a synonym for community in this case. She says, "But I'm on the other side now too: I realized that despite my lack of Jewish ancestry and strange though it seemed, I had somehow joined into the the Peoplehood part of Judaism as well as the religious part, and that was when I converted." Debbie B. converted to Judaism after many years as an intermarried partner. Because intermarriage is full of challenges, she waited to convert until she felt culturally prepared. Although Debbie B.'s ethnic bond to Judaism is not through matrilineal ties, she is culturally bound as a part of her Jewish community (IFF_Telling Jewish Grandparents About Baptism).

Girlie explains cultural Judaism from the position of her potential in-laws. As the girlfriend of their Jewish son, Girlie is the non-Jewish partner and feels stigmatized for this reason, even though her future in-laws are non-religious, somewhat like herself. Girlie says, "Judaism is very important to them, of course, but primarily in a cultural sense." Girlie's case is relevant because her post clarifies the various struggles with interfaith dating and marriage, particularly with the complication of ethnicity (JOI_Boyfriend's parents).

Intermarriage can suffer if the non-Jewish partner does not appreciate the cultural significance of Judaism. Andrew, a member of the joi.org discussion board, believes this statement holds significant value in light of the difficulties associated with intermarriage. However, he does appreciate the culture his Jewish spouse brings to their intermarriage and sees "Judaism [not] as a religion but as a culture and therefore an intermarrage with a jew who has a remote interest in what in means to be 
a jew and the responsibilties that jews inherit (the burden of thousands of years of guilt, repression and persecution) can overwhelm a marriage if the non-jew spouse does not share that responsibility." Andrew's intermarriage is not overwhelmed by his Jewish spouse and he believes his future wife should influence their children's culturally Jewish affiliations. Andrew does understand the struggles associated with intermarriage and says, "reconciling the (historical) pressures that jews face when marrying non-jews with the love and commitment to a happy household and possibly a family are very stressful." Despite the difficulties of intertwining Jewish culture and intermarriage, Andrew discusses the ability to conquer those obstacles (JOI_children family).

If an individual identifies with Judaism culturally and not religiously, it can be difficult to pass on the religious traditions of Judaism once an interfaith family is formed. Margot is an example of this phenomenon. She comes "from a nonpractising Jewish family" that "never went to shul, did celebrate Jewish holidays in abbreviated form, and shared an intense sense of Jewish 'cultural' identity." For this reason, she feels her interfaith marriage will suffer once she and her partner decide to have children. Margot raises questions about the survival intermarriage that is based on cultural Judaism and not religious Judaism. She wonders "if this type of arrangement is stable and tenable over time." Margot says, "it never occurred to me that I wouldn't marry someone Jewish." Without the influence of a religious Jewish partner, Margot believes that intermarriage, not rooted in religious traditions, will be far less likely to succeed (JOI_What do you all think). 


\section{CHAPTER IV}

\section{DISCUSSION}

This study examined discussion board posts about Jewish interfaith relationships and intermarriage to determine who was participating, what was discussed, and how the discussion themes were framed. The literature review conducted in preparation for this study identified four topics of conversation about Jewish intermarriage: romantic love, independence, concern for children, and ethnicity. The messages analyzed on interfaithfamily.com and joi.org showed that these four topics are not restricted to the scholarly literature, but are also discussed in public among individuals concerned with Jewish interfaith relationships and intermarriage who come from a mix of religious affiliations. With romantic love as a backdrop, independence, concern for children, and ethnicity comprise relatively close portions of the overall data set (see Figure 1.1).

Romantic love makes up the lowest percentage of codes. Comprising $12.8 \%$ of the codes in the data set, it is the least talked about topic. Individuals may talk about romance less because they understand desire or attraction as a constant. Individuals probably take romantic love for granted when it comes to considering their interfaith relationship. 


\section{Percent Coded Topics}

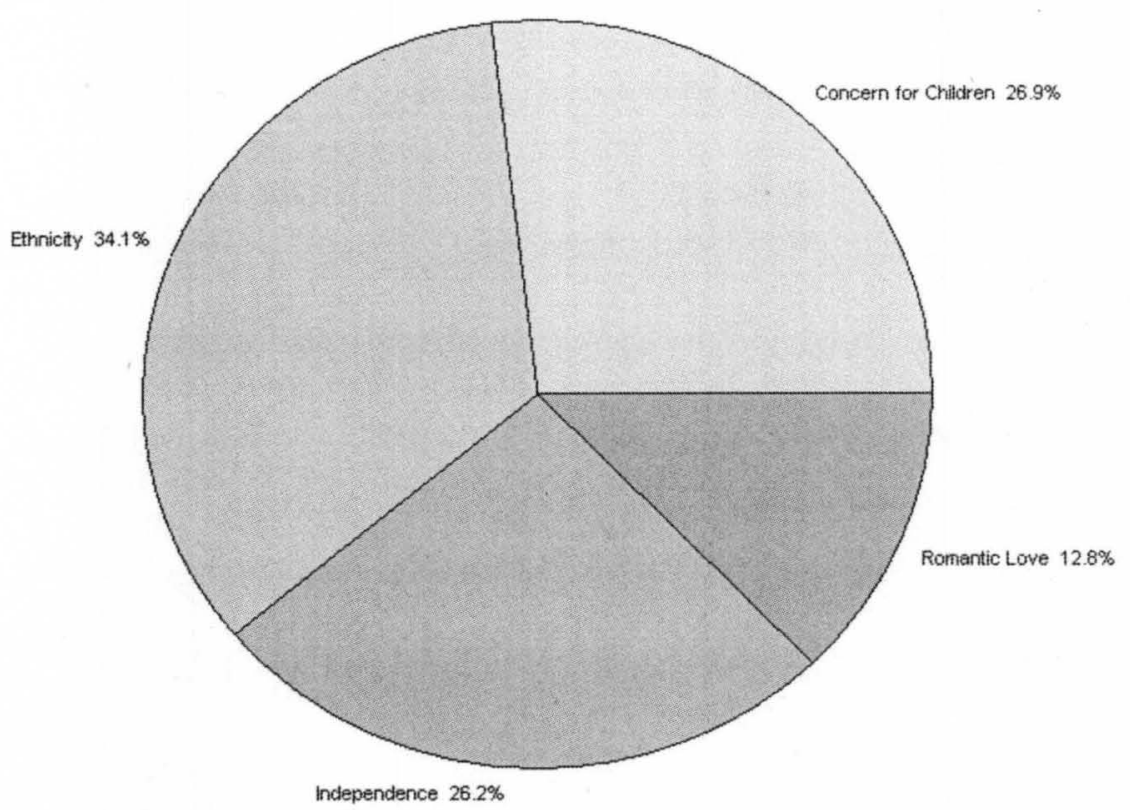

Figure 1.1 Percent Coded Topics

In addition, many posts about romantic love were likely written by young adults, possibly caught in a web of emotion and desire that precedes concern about intermarriage. Some individuals indicated that they were in college or still living at home with their parents, suggesting that they are young adults. The small percentage of individuals writing about romantic love may be an artifact of sampling. The young adult population might be more inclined to discuss romantic love on other social networking sites or face to face. 
The next largest topic discussed is independence. Codes about independence make up $26.2 \%$ of the data. Similar in size to the remaining two topics, posts about independence revealed several important conclusions. Individuals who discussed independence were for the most part already decided on the topic of intermarriage. They commented on an impending conversion, having been accepted or not accepted by family members, and the level with which they intended to observe religion. A few discussed their regret for having intermarried. Because most had come to a conclusion about intermarriage before posting to the discussion boards, they may have chosen to post on interfaithfamily.com and joi.org for advice about their plans concerning intermarriage. Ironically, by posting on discussion boards, individuals who were coded for independence relinquished a part of their individuality by engaging in a community, community being the online discussion boards.

The third most frequently discussed topic is concern for children. It makes up $26.9 \%$ of the codes, only $.7 \%$ more than independence. Because children are a likely result of intermarriage, individuals discussing intermarriage often express concern about how to raise their children.

Christians discuss concern for children more frequently than any other faith group. For many Christians, religion is a choice. By contrast, a Jewish woman's child is Jewish from birth. Perhaps Christians post more frequently about concern for children because the children of a Jewish man and a Christian woman will have the opportunity to choose either religion. The options accompanying this type of intermarriage may explain why Christians posted more frequently in concern for children. 
Comprising $34.1 \%$ of the data, ethnicity is the highest coded topic. Ethnicity may be coded most frequently because it plays a significant role in the choice to intermarry. A Jewish individual who associates with Judaism only by ethnicity might view intermarriage as complicated, but acceptable. Obstacles include differing faiths, religious traditions, observance, and culture. The decision to intermarry often depends on whether the Jewish partner is religiously or culturally affiliated with Judaism.

The breakdown by religious affiliation presented the following statistics: $26 \%$ were Jewish, $29.3 \%$ were Christian, and $44.7 \%$ were Other/Unknown. Clearly, individuals from both Christian and Jewish faiths are talking about Jewish interfaith relationships and intermarriage on website discussion boards (see Figure 1.2).

Few individuals who identified themselves as Jewish identified themselves with a branch of Judaism (Orthodox, Conservative, Reform). It can be speculated that because Reform is the only branch that allows intermarriage, fewer Orthodox and Conservative Jews intermarry, and most assume that readers would take affiliation with Reform Judaism for granted.

Females posted almost three-quarters of the discussion board messages. Thirty-five (20.7\%) were written by males, $119(70.4 \%)$ were written by females, and $15(8.9 \%)$ were indeterminate. Although not surprising, the percentage is significant and worth mentioning. It may be that women communicate their feelings about domestic issues more than men. For this reason, more than three times as many women posted than men (see Figure 1.3). 


\section{Posts According to Religious Affiliation}

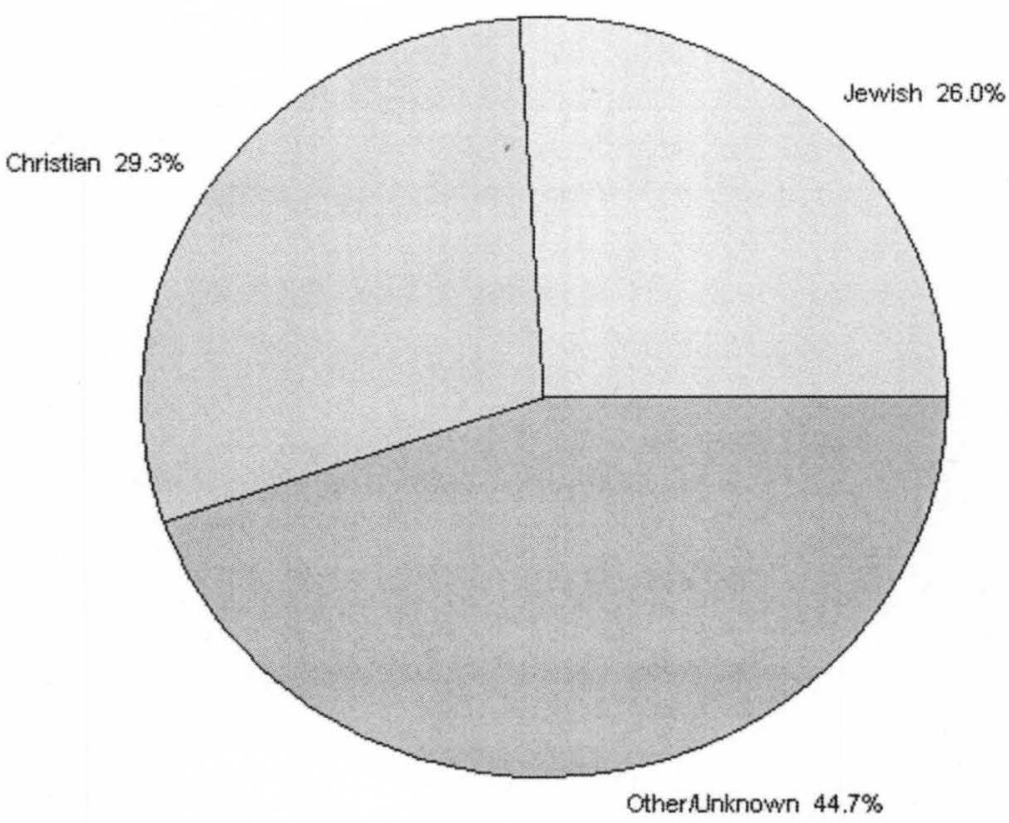

Figure 1.2 Posts According to Religious Affiliation

The relationship between religious affiliation and topic is important to note because it explains who in the data set is discussing the four topics identified as scholarly issues about Jewish intermarriage. The most frequently discussed topic among Jews is ethnicity (32.4\%). Perhaps Jews discuss ethnicity most often because many Jews are concerned about their ties. Christians discuss concern for children most frequently (35.2\%). Because children born to Jewish women are Jewish by birth, it is possible that fewer Jews posted in this topic because religion is a foregone conclusion in marriages between Christian men and Jewish women. 


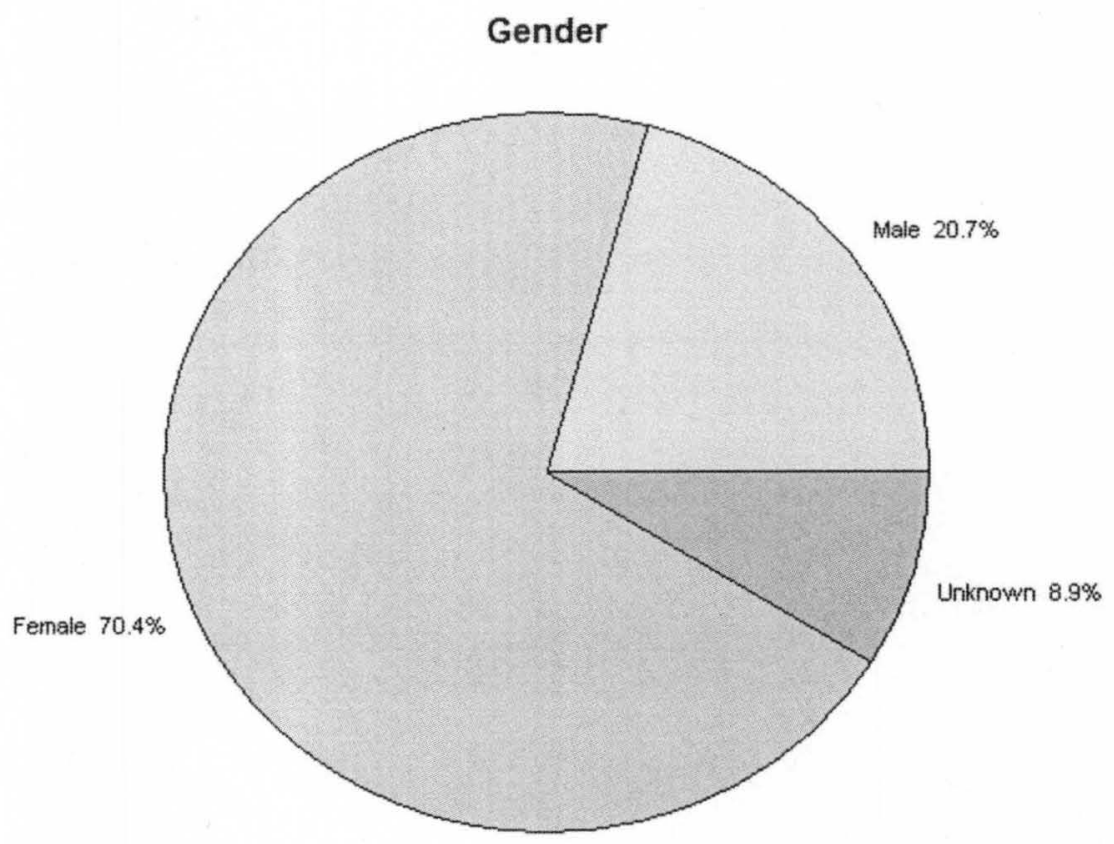

Figure 1.3 Gender

The comparison of topics and religious affiliations shows that both Christians and Jews discussed ethnicity and concern for children most often (see Figure 1.4).

Because most posts concern problems and struggles associated with interfaith relationships and intermarriage, it is hard to determine how many individuals are happy in an interfaith relationship or intermarriage. The data set is a small sample of the interfaith community, only 169 cases amid tens of thousands of interfaith couples. Therefore, the problems with interfaith relationships and intermarriage that are seen in this population sample could well be unrepresentative. That is, people who are experiencing problems post to interfaithfamily.com and joi.org, but those whose interfaith relationships and intermarriages pose no significant problems do not. No poll assesses the happiness of Jewish interfaith relationships and intermarriages. 
Topic and Religious Affiliation

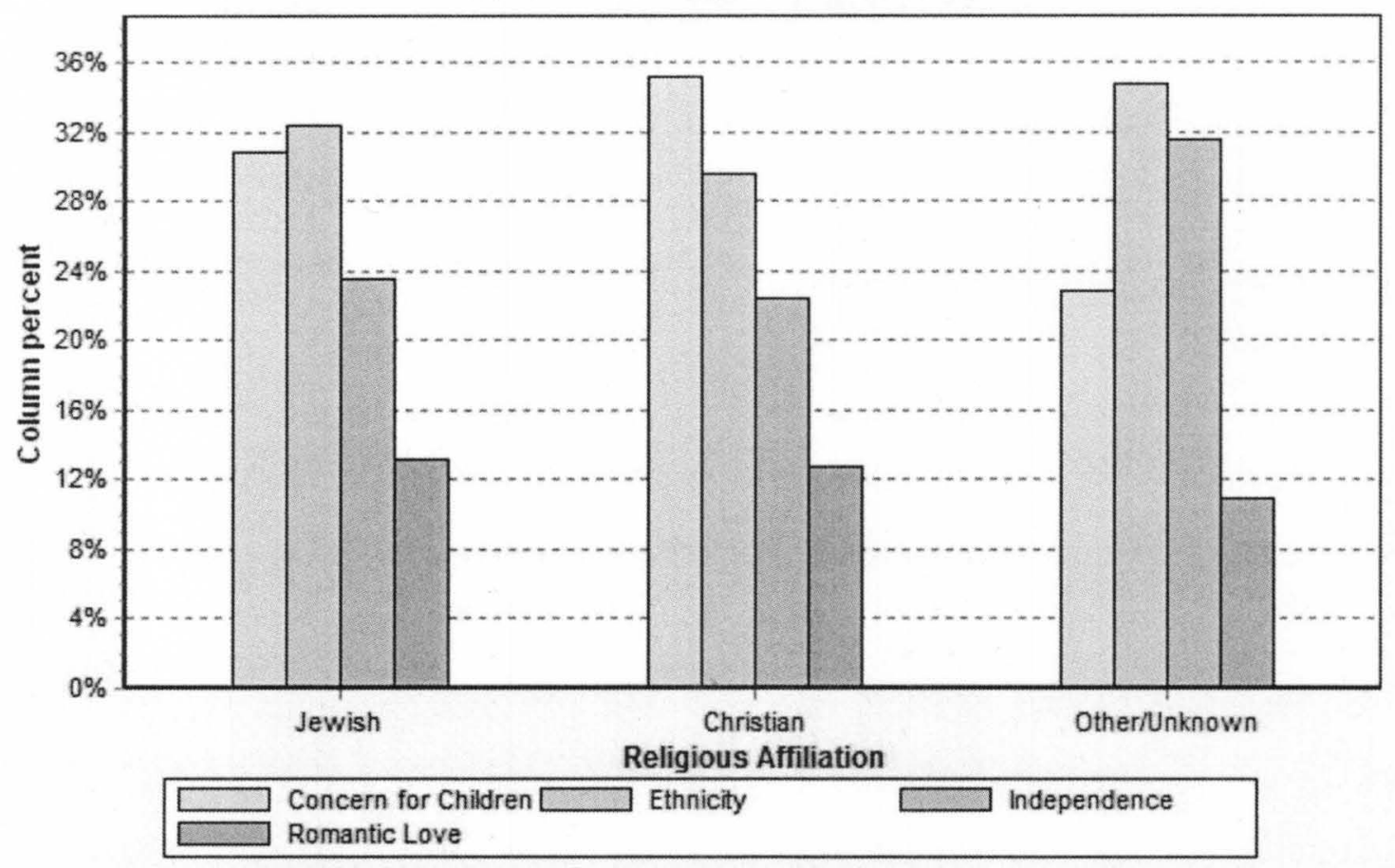

Figure 1.4 Topic and Religious Affiliation

QDA Miner, the software program utilized for this research study, provided advanced assistance with the coding and organization of text. Sorting and analyzing the data was made significantly easier with the use of this computer program. Once all codes were flagged, text merely needed to be pulled from the program and analyzed. Making reasonable generalizations based on the posts from interfaithfamily.com and joi.org would have been far more difficult without the assistance of QDA Miner.

In light of the results of this research study, it is imperative to note the evolving pluralism in the Jewish community. Sol Roth, in his article titled "Religious Pluralism: A Problem or A Solution?" says, "Classical Judaism advocates uniformity 
of conduct in Jewish life. It allows, indeed, encourages differences in views, so long as these do not conflict with Judaism's fundamental principles" (163). Roth's comment holds true within the topic of intermarriage. Judaism, outside of the Reform branch, forbids intermarriage. Orthodox and Conservative are attempting to keep their populations intact by decree. By denying pluralism through intermarriage, the Jewish population should presumably increase. However, as was mentioned in the introduction, the Jewish population has remained static for some years. Because the United States is an amalgamation of religions and ethnicities, it is not surprising that many individuals choose to marry outside of the group of their birth.

\section{Conclusion}

Jewish intermarriage became increasingly popular in the mid-twentieth century. Because it has remained steady for some time, it is important to research how individuals discuss interfaith relationships and intermarriage. This research study showed that the four topics of discussion are not just community issues, they are personal issues that have positive and negative dimensions. The discussion boards examined in this study reveal how individuals experience community issues. Jewish interfaith relationships and intermarriage are presently topics of conversation involving romantic love, independence, concern for children, and ethnicity.

This study is an example of an effective way to study conversations about Jewish intermarriage. It provides a relevant contribution to communication research because discussion boards provide researchers with an unobtrusive view of a particular population. This study utilized discussion board posts as a format for 
systematically analyzing conversations on an emotionally-charged subject.

Subsequent studies might also employ Internet discussion boards as a basis for population samples. 


\section{REFERENCES}

Auerbach, Carl F. \& Silverstein, Louise B. An Introduction to Coding and Analysis: Qualitative Data. New York: New York University Press, 2003.

Barak, Azy \& Gluck-Ofri, Orit. "Degree and Reciprocity of Self-Disclosure in Online Forums." CyberPsychology \& Behavior. 10.3 (2007): 407-17.

Campbell, Heidi. "Making Space For Religion In Internet Studies." Information Society 21.4 (2005): 309-15.

Campbell, Heidi. Exploring Religious Community Online: We are One in the Network. New York: Peter Lang, 2005.

Chama, Joshua R. C. "Finding God on the Web." Time 149.1 (1996): 52-59.

Cohen, Steven M. \& Eisen, Arnold M. The Jew Within: Self, Family, and Community in America. Bloomington: Indiana University Press, 2000.

Freedman, Samuel G. Jew vs. Jew: The Struggle for the Soul of American Jewry. New York: Simon \& Schuster, 2000.

Hartman, H. and Hartman, M. "Jewish Attitudes Toward Intermarriage." Journal Of Contemporary Religion. 16.1 (2001): 45-69.

Keen, Jim. Inside Intermarriage: A Christian Partner's Perspective on Raising A Jewish Family. New York: URJ Press, 2006.

Kosmin, Barry A., et al. Highlights of the CJF 1990 National Jewish Population Survey. New York: Council of Jewish Federations, 1991. 
Kosmin, Barry A. \& Keysar, Ariela. American Religious Identification Survey 2008 Summary Report. Hartford, CT: Institute for the Study of Secularism in Society \& Culture, 2009.

Lazerwitz, Bernard. "Jewish-Christian marriages and Conversions." Jewish Social Studies, 43 (1981): 31-46.

Center for Judaic Studies and Contemporary Jewish Life. Mandell L. Berman Institute North American Jewish Data Bank. Storrs, CT: American Jewish Committee, 2003.

McGinity, Keren R. Still Jewish: A History of Women and Intermarriage in America. New York: New York University Press, 2009.

Parks, Malcolm R. \& Kory, Floyd. "Making Friends in Cyberspace." Journal of Communication. 46.1 (1996): 80-97.

Patton, Michael Q. Qualitative Research \& Evaluation Methods. Thousand Oaks, CA: Sage Publications, 2002.

Roth, Sol. "Religious Pluralism: A Problem or a Solution?" Judaism. 36.2 (1987): 162 .

Tobin, Gary A. Opening the Gates: How Proactive Conversion Can Revitalize the Jewish Community. San Francisco: Jossey-Bass, 1999. 


\section{CURRICULUM VIATE}

NAME: Miriam Cecil Kan

ADDRESS: 1904 Duker Ave.

Louisville, KY 40205

DOB: $\quad$ Lexington, Kentucky - January 6, 1981

EDUCATION

\& TRAINING

B.A., English

University of Montana

2003

Graduate Assistant

Campus Health Services, Office of Health Promotion

University of Louisville

2011-2012

Graduate Assistant

Communication Department

University of Louisville

2010-2011 